\title{
Universiteit
}

Leiden

The Netherlands

\section{Conflicts law and public policy in Egyptian family law: Islamic law through the backdoor}

Berger, M.S.

\section{Citation}

Berger, M. S. (2002). Conflicts law and public policy in Egyptian family law: Islamic law through the backdoor. American Journal Of Comparative Law, 50(3), 555-594. Retrieved from https://hdl.handle.net/1887/28183

Version: $\quad$ Not Applicable (or Unknown)

License: $\quad$ Leiden University Non-exclusive license

Downloaded from: https://hdl.handle.net/1887/28183

Note: To cite this publication please use the final published version (if applicable). 


\section{MAURITS S. BERGER}

\section{Conflicts Law and Public Policy in Egyptian Family Law: Islamic Law Through the Backdoor}

\section{INTRODUCTION}

The rules of contemporary Egyptian conflicts law can be found in Articles 10 to 28 of the Civil Code of 1949. These conflicts rules are quite similar to those of most civil law countries, although they may appear a bit old fashioned in the light of the recent developments in Western conflicts law. Conflicts rules set the conditions under which the national courts may apply foreign laws. The application of foreign laws will not be permitted, however, when they violate the socalled public policy. This is a concept of European origin denoting the legal principles regarded as essential for the national legal order. It was introduced in Egyptian legal doctrine during the nineteenth century and first codified in the Egyptian Civil Code of 1949. In this article I will analyze how, with regard to matters of personal status, this notion has been interpreted in Egyptian case law and legal doctrine after the enactment of the Civil Code. I will demonstrate that the Egyptian concept of public policy in fact introduces concepts of Islamic conflicts law, which renders it both in substance and procedure very different from the meaning of public policy in most civil law countries.

A few remarks on the methodology of this article are in order. The analysis of the concept of Egyptian public policy implies a rather complicated form of comparative law, since Egyptian law and literature use a legal language familiar to Western jurists for an equally familiar legal concept, but this concept itself is based on rules and concepts of Islamic law. The approach to this problem will be in four stages: first, a short outline of Egyptian conflicts law and its European and Islamic sources will be presented, followed by an introduction to the Egyptian concept of public policy. Then a survey of all Egyptian case law on public policy since 1949 will be presented,

Maurits S. Berger (L.L.M. and M.A. in Arabic Studies, both University of Utrecht) is writing his Ph.D. at the University of Amsterdam.

This article is part of my Ph.D. research on public policy in contemporary Egyptian law. I am indebted to my supervisors Professor R. Peters and Professor Th. M. de Boer of the University of Amsterdam. 
which will provide the material for a final analysis of the concept of Egyptian public policy in the fourth and last section.

\section{Egyptian Conflicts Law}

\subsection{Historical background}

When studying Egyptian conflicts law, one gets the impression that it is exclusively based on European conflicts law. I will argue that Islamic conflicts law is a subsidiary - and perhaps the main source of Egyptian conflicts law in matters of personal status, although it is never mentioned as such by the Egyptian legal literature. ${ }^{1}$ A short overview of the basic principles of Islamic conflicts law is therefore in order, followed by the historical developments of Egyptian conflicts law up to 1949 , the starting point of the period covered by this study.

\section{Islamic conflicts law ${ }^{2}$}

Islamic law disregards state borders and concepts like nationally or domicile and only recognizes two categories of legal subjects: Muslims and non-Muslims. The non-Muslims are subdivided into three legal categories: the harbis are those who reside outside the Islamic territories, the dhimmis are those who reside within the Islamic territories, and the musta'mins are foreign residents or visitors, i.e., the harbis who are allowed temporary entry into the Islamic territories.

With regard to Muslims, Islamic law is a personal law by being applicable regardless whether the Muslim travels or resides in or outside Islamic territory. With regard to non-Muslims, Islamic law is a territorial law by being applicable to anyone traveling or residing in Islamic territory, with the exception of matters of personal status and religious affairs; in those cases Islamic conflicts law adheres to the

1. An exception is 'Abd Allah, al-Qanun al-Duwali al-Khass al-Masri 69-72 (1954) and (with his name spelled as Abdalla) "La philosophie du législateur égyptien en matière de conflit des lois," 340 L'Egypte Contemporaine 154-58 (April 1970). Some Egyptian authors on conflicts law give a short overview of Islamic conflicts law but without indicating its relevance to contemporary Egyptian conflicts law: 'Abd alRahman, Tanazu 'al-Qawanin 44-50 (1969); Ibrahim, al-Qanun al-Duwali al-Khass: al-Tanazu al-Qawanin 21-23 (1997); Kurdi, Durus fi al-Qanun al-Duwali al-Khass 103-25 (1996/7); Salama, 'Ilm Qa'ida al-Tanazu' wa al-Ikhtiyar bayn al-Shara' '`' 18891 (1996).

2. See, e.g., Arminjou, "Les sytèmes juridiques complexes et les conflits de lois et de jurisdiction auxquels ils donnent lieu," 2 Receuil des Cours de l'Academie de Droit International de La Haye 159-72 (1949); Fattal, Le statut légal des non-musulmans en pays d'islam (1958); Hamidullah, The Muslim conduct of state (1945); Khadduri, The law of war and peace in Islam (1940); Mahmassani, al-Qanun wa al-alaqat alduwaliyya fi al-islam (1972), Maraghi, al-Tashri al-Islami li-ghayr al-muslimin (n.y.); Qardawi, Ghayr al-Muslimin fi al-Mujtama al-Islami (1985); Samdan, Contracts' conflict rules in Arab private international law: a comparative study on principles of Islamic and civil legal systems (thesis, 1981); Zaydan, Ahkam al. dhimmiyin wa al-musta'minin fi dar al-islam (1976). 
personality of laws by allowing non-Muslims a relative legislative and judicial autonomy. This regards the dhimmis and, to a similar extent, the musta'mins.

It would be tempting to compare the musta'min with the modern notion of the "foreigner" or "legal alien." This is only correct if one makes an additional religious qualification: a musta'min can be compared to a "non-Muslim foreigner," because a Muslim, regardless of his origin or nationality, always receives the same legal treatment as the resident Muslim. A Muslim foreigner, from an Islamic legal point of view, is a contradiction in terms. This fundamental rule will be of relevance to contemporary Egyptian conflicts law, as we will see below.

It has been argued that the concept of conflicts law is unknown to Islamic law because the Muslim and non-Muslim courts within the Islamic territory each applied their own religious laws (non-Muslim courts only with regard to personals status law, Muslim courts also in all other domains). ${ }^{3}$ The legal domains were therefore separated along religious lines. When a conflicts of law occurred because a dispute arose between a Muslim and non-Muslim, Islamic law would always apply by virtue of the involvement of a Muslim party. Hence, the process of taking into account a "foreign" law - i.e., the law pertaining to the jurisdiction of a court of different religion - was never a matter of consideration for these courts.

\section{European influences}

With the arrival of European residents in Islamic territories, the system of separate jurisdictions was extended to them too. Privileges with regard to jurisdiction were granted to foreigners on a limited scale by Egyptian authorities since the 13th century AD. After the 16 th century, when the foreign merchants settled in the ports of Egypt and became residents on a more or less permanent basis, these privileges obtained the form of bilateral treaties, known as the Capitulations. The foreign communities, musta'mins from an Islamic legal point of view, acquired a unique status: they administered their own internal affairs and their judicial autonomy was extended far beyond matters of personal status. ${ }^{4}$

3. Benattar, "Problème de droit international privé dans les pays de droit personnel," 2 Recueil des Cours de l'Academie de Droit International de La Haye 11 (1967); Elgeddawy, Relations entre systèmes confessionanels et lä̈que en Droit International Privé 29 (1971); Salama, supra n. 1, at 191-92. For the opposing view, see Cardahi, "La conception et la pratique du droit international privè dans l'Islam. Etude juridique et historique," 2 Receuil des Cours de l'Academie de Droit International de La Haye 589 (1937); Charfi, "L'influence de la religion dans le droit international privé des pays musulmans," 3 Receuil des Cours de l'Academie de Droit International de La Haye 383 (1987).

4. See, e.g., Abdalla, supra n. 1, at 153-55; Jambu-Merlin, "Essai sur l'histoire des conflicts de lois au Levant et en Afrique du Nord," Revue critique de droit interna- 
By the end of the 19th century Egypt embarked on the process of unification of its divided courts and their respective laws. For the first time national conflicts rules were formulated, starting with the introduction of the civil code for the "Mixed Courts" (for disputes between Egyptians and foreigners, or between foreigners of different nationalities) in 1876 and ending with the conflicts rules of the Civil Code in 1949 (which was promulgated at the moment when the abolishment of the Mixed Courts became effective). Although the French Civil Code was the main source of inspiration during this period, the Egyptian legislature apparently made elaborate comparative studies of the Italian, Polish and German codes when preparing the conflicts rules of the Civil Code of $1949 .^{5}$

The European concepts from which Egyptian conflicts law originated seem to be the opposite of every concept in Islamic law. While Islamic law assumes the existence of a single Islamic territory, a single Islamic law and a single Muslim nation, European law in an early stage recognized the many different territories, each with its own people and laws. ${ }^{6}$ It was not unusual for European judges to have to consider another law than their own, while their Muslim colleagues would apply only Islamic law. With the disintegration of the Ottoman Empire after 1918 into a multitude of states, each with its own people and laws, the Islamic concepts of territory and nation finally gave way to a situation similar to that of Europe. ${ }^{7}$

tional privè 11-14 (1958); Linant de Bellefonds, "La jurisprudence égyptienne et les conflits de lois en matière de Statut Personnel," 3 Journal de Droit International 827 (1960); Szaszy, Droit International Privé Comparé. Traité de législation comparée avec référence spéciale au droit égyptien et musulman 202-03, 208 (1940). See for a social-economical background: Ashtor, Levant Trade in the Late Middle Ages (1983); Desomogyi, A short history of Oriental trade (1968); Ilbert \& Yannakakis, Alexandria 1860-1960. The brief life of a cosmopolitan city (1997).

5. Abdalla, supra n. 1, at 155-56. See also the Explanatory Memorandum to the Draft Law of the Civil Code (al-Mudhakkira al-Idahiyya li-Mashru 'al-Qanun alMadani), published as part of the parliamentary Collection of Preparatory Works (Majmu'a al-A'mal al-Tahdiriyya), hereafter referred to as the Explanatory Memorandum.

6. The terms "citizen" or "nationality" are unknown in Islamic law. It is debated in contemporary literature whether the concepts of these terms existed in Islamic law. Many argue that the concept of nationality was not existent in Islamic law which distinguished only according to religion, meaning that Muslims were "full" citizens and non-Muslim residents (dhimmis) were "foreigners," "citizens of second rank" or "subjects" (Belkaziz, La nationalité dans les Etats arabes 3 (1963); Boghdadi, Origine et technique de la distinction dese statuts personnel et reél en Egypte 80 (1937); Cardahi, supra n. 4, at 521; Elgeddawy, supra n. 4, at 54; Fattal, supra n. 2 at 23, 367; Khadduri, supra n. 2, at 198; Saba, L'islam et la nationalité 38 (1931). It can be argued that authors (often Muslims) who present the opposite view, i.e. of historical equality of citizenship enjoyed by Muslims and non-Muslims, usually do so in order to give historical justification to the national unity of modern Muslim countries (Abdel Gawad, "L'attitude de l'Islam a l'egard des non-muslumans (etats et individues)," 37 Revue al-Qanoun wal Iqtisad 235 (1967); Qadat, Mu'amalat ghayr al-Muslimin fi alislam 592 (1989, Vol. 2), Qardawi, supra n. 2, at 5.

7. This development was of course not as clear-cut as depicted here. The Islamic territory and nation has always been divided, whether in semi-autonomous or inde- 
Still, in formulating national conflicts rules based on the European model, Egypt tried to relate to European concepts close to its own. It has for instance been argued that the doctrine of conflicts law as developed by the Italian Mancini in the late $19^{\text {th }}$ century was of great influence of Egyptian conflicts law because Mancini's doctrine provided more familiar concepts to countries with a tradition of personal laws. ${ }^{8}$ For instance, Mancini was a strong supporter of the personality of laws, e.g. that a person was entitled to have his national "private" law applied irrespective of the forum. ${ }^{9}$ Egyptian conflicts law adhered to this principle with regard to matters of personal status, using nationality rather than domicile as connecting factor in matters of personal status in order to allow the large foreign communities in Egypt to have their national law applied, even if they had been residing in Egypt all their life. ${ }^{10}$

\section{Stagnation of Egyptian conflicts law after 1960s}

Egyptian conflicts law was a dynamic law until the 1960s. Since then the courts have produced very few cases on conflicts law and the legal doctrine came to a virtual standstill. The main cause should probably be sought in the expulsion and exodus of the large foreign community in the late 1950s and the subsequent economical and political isolation of Egypt. Both factors attributed to the loss of practical relevance of Egyptian conflicts law. The period of isolation might also account for a lack of academic and legal exchange with countries like France which was the main source of inspiration for Egyptian legal doctrine. The developments of European conflicts law since the 1960s, with concepts like conflicts law, party autonomy, functional allocation, have passed by Egypt almost unobserved. ${ }^{11}$ From a European legal point of view, Egypt has consolidated its conflicts rules in a period which now seem to be "quiescent years"12 in the evolution of conflicts law.

pendent states. What is of relevance here, however, is not the historical facts of nationhood but the general concepts of law.

8. Abdalla, supra n. 1, at 158-62; Jambu-Merlin, supra n. 4, at 28, 30.

9. Linant de Bellefonds (supra n. 4 at 825) argues that "the Moslem outlook" on the extensive concept of personal status is much earlier than Mancini's.

10. 'Abd Allah admits the merit of domicile as a connecting factor, but argues that using nationality is more advantageous to the many foreigners residing in Egypt since it prevents Islamic law being applied to them in matters of personal status ('Abd Allah, al-Qanun al-Duwali al-Khass 91, 527 (1969) and Abdalla supra n. 1, at 166). See also Berger, "Regulating tolerance: protecting Egypt's minorities," in [title forthcomingl for a discussion of the dichotomy between nationals and residents, based on an Alexandrian court case dealing with the Greek and Italian communities in Alexandria in the 1950s.

11. In 1996, Salama (supra n. 1, at 13) was the first who advocated a choice of law approach to conflicts law.

12. De Boer, "Forty Years On: The evolution of postwar international law in Europe," in Forty Years On: The evolution of postwar private international law in Europe 2 (1990). 
A reversal of this situation seems to be taking place since the 1980 s, which might be attributed to the "opening" of Egyptian society and its economy to the outside world. Since then, Egyptian university libraries have resumed the acquisition of foreign legal literature on conflicts law and Egyptian authors on conflicts law have become quite prolific, although the content of their writings is still not much different from that of their colleagues in the 1960s. This fossilized appearance of Egyptian conflicts law may change once new case law is being produced. On the other hand, while in matters of conflicts law the Egyptian courts in the 1950s and 1960s issued many contradictory rulings (see below, under 1.2), the subsequent period of relative calm in this field has given the legal literature ample time to shape a unified doctrine. Typical of the period of the 1980s and 1990s is that the legal literature has become more unanimous on the Islamic character of public policy. I am of the opinion that this phenomenon is a solidification of a long-existing prevalent opinion rather than the result of the social-political trend of "Islamic resurgence." I will return to this issue in the last section.

\subsection{Egyptian conflicts law: the role of religion and religious law \\ Religion as connecting factor}

In all matters of marriage, divorce and succession, the conflicts rules of the Civil Code use as connecting factor the nationality of one (or both) of the parties involved. Domicile is of little or no relevance. ${ }^{13}$ Religion becomes of relevance in three instances: when one of the spouses has the Egyptian nationality (Article 14), when a foreign couple celebrates their marriage in Egypt (Article 20), or when the applicable rules of the foreign law violate the public policy and morals of Egypt (Article 28). The first two situations are conflicts rules which needs further clarification in order to get a clearer picture of the role of public policy.

Article 14 stipulates that Egyptian law applies to marriage, its legal effects and divorce if one of the spouses had the Egyptian nationality at the time of the conclusion of the marriage. ${ }^{14}$ Article 20 stipulates that Egyptian law applies to a (marriage) contract concluded in Egypt (lex loci actus). In both instances the question rises:

13. Cf. 'Abd Allah, supra n. 10, at 527. One of the few occasions when a court ruled differently was the Cairo Court of First Instance on 22 June 1955, 12 Revue Egyptienne de Droit International 224ff (1956), arguing that a person of Maltese nationality but born and residing in Egypt had more links with Egyptian law as the law of his domicile than with Maltese law.

14. This conflicts rule used to be common in most European laws, but has acquired a rather curious aspect in the case of the Egyptian woman who marries a foreigner. On the one hand, she will most probably lose her Egyptian nationality (depending on the conditions as set in Article 12 of the Egyptian Nationality Law of 1975), but, on the other hand, Egyptian law will remain applicable to her marriage and divorce (conflicts rule of Article 14 Civil Code). 
which Egyptian law? Because Egyptian personal status law is a plurality of laws: there is not one personal status code for all Egyptians, but a separate code for almost every one of the fifteen religious communities within Egypt. ${ }^{15}$ All these personal status laws are based on religious sources. The personal status law for Muslims is the only one which has been promulgated by the Egyptian legislature, the others by local or foreign religious authorities. This means that, when Articles 14 and 20 apply, one has to resort to Egyptian internal conflicts law to determine which of the personal status laws is applicable. ${ }^{16}$ These rules of internal conflicts law, which are laid down in Law 462 of 1955 , use religion as the only connecting factor. In brief, the Egyptian court will refer to the personal status law for Muslims when at least one of the spouses is Muslim, or when the non-Muslim spouses belong to different rites or sects. If, on the other hand, the spouses are non-Muslims and both belong to the same rite and sect, the Egyptian court will refer to the relevant Egyptian non-Muslim law. ${ }^{17}$

These internal conflicts rules may yield surprising results for the foreign spouses involved. For instance, if a Catholic Frenchman wants to divorce from his Catholic Egyptian wife with whom he had entered into a civil marriage in France, he will be denied his divorce by the Egyptian court because Egyptian Catholic law does not allow divorce. ${ }^{18}$ The rule of Egyptian internal conflicts law that Islamic law applies in case of difference in religion, rite or sect also leads to curious results. The marriage between a Catholic Egyptian and a Greek-Orthodox Greek was considered void by the law of the Greek husband, but valid according to the applicable Islamic law. ${ }^{19}$ And the application of Islamic law also gives the husband the right of unilateral divorce (talaq), as happened to the Greek-Orthodox Greek who

15. Egypt recognizes one Muslim, two Jewish and twelve Christian communities, with a total of eight personal status laws: Muslim, Jewish, Coptic-Orthodox, GreekOrthodox, Syrian-Orthodox, Armenian-Orthodox, Catholic and Protestant. (The number of laws is less than the communities because some communities share the same law.)

16. One prominent author is of the opinion that the Egyptian internal conflicts rules also apply when both spouses are foreigners, on the condition that their national personal status law is a religious and not a civil law (Riyad, Tanazu'al-Qawanin wa al-Ikhtisas al-Qadai al-Duwali wa Athar al-Akham al-Ajnabiyya 232-34 (1998/9)).

17. See, e.g., Berger, "Public policy and Islamic law: the modern dhimmi in contemporary Egyptian family law," 8 Islamic Law and Society (2001); Meinhofer, Religiöses Recht und internationales Privatrecht dargestelt am Beispiel Agypten (1995).

18. So far, the Court of Cassation has not ruled in such a case, but the case law of lower courts like the Cairo Court of First Instance provides similar examples: No. 53, Year 1952, 2 June 1952; No. 20, Year 1953, 17 November 1953 (both unpublished, quoted by 'Abd Allah, supra n. 11, at 260).

19. Court of Alexandria, 26 February 1952, 9 Revue Egyptienne de Droit International 159ff. (1953). 
was married to an Coptic Egyptian woman. ${ }^{20}$. Catholic Egyptians are not allowed to divorce at all, however, not even when Islamic law is applicable, which was the reason that a Catholic Egyptian and a Jewish Italian were refused divorce. ${ }^{21}$

Occasionally, the lower courts misapplied these conflicts rules. The Cairo Court of First Instance, for example, on several occasions disregarded the nationality of a foreign couple (which, according to the conflicts rule, determines the applicable law to their marriage and divorce), but, based on the religion of the spouses, directly referred to the internal conflicts rules. ${ }^{22}$ And sometimes the courts interpreted Article 14 by directly applying the religious law of the Egyptian spouse without considering the internal conflicts rule which assigns Islamic law as the applicable law in mixed religious marriages. ${ }^{23}$ According to the legal doctrine as upheld by the Court of Cassation, these rulings are indeed misapplications, although the contrary has also been argued in the legal literature. ${ }^{24}$

20. Court of Cassation, Majmu'at al-Ahkam li-Mahkamat al-Naqd, No. 117, Year 56, 22 December 1987.

21. Court of Cassation, Majmu'at al-Ahkam li-Mahkamat al-Naqd, No. 17, Year 27, 17 November 1960. This particular rule is stipulated in Article 99/7 of the Decree on the Organisation of the Shari'a Courts. Earlier, the Cairo Court of First Instance had refused on the same grounds the divorce between an Egyptian Catholic and an English Protestant (2 February 1954, 19 Majallat al-Tashri wa al-Quda, 360 (1954)).

22. (not published, quoted by 'Abd Allah, supra n. 10, at 311-12):

- No. 34, Year 1950, 27 February 1951 (Jewish Italian couple: Egyptian Jewish law applicable);

- No. 53, Year 1951, 1 January 1952 (Greek couple, both Greek-Orthodox, Egyptian Greek-Orthodox law applicable);

- No. 66, Year 1952, 18 March 1952 (Jewish American couple: Egyptian Jewish law applicable);

- No. 74, Year 1950, 2 June 1953 (British Catholic couple: Egyptian Catholic law applicable).

23. - Alexandria Court of Appeal, 21 May 1950, 6 Revue Egyptienne de Droit International 237 (1950): Egyptian Jewish law applies to the marriage between Jewish Egyptian and Catholic Italian;

- Alexandria Court of First Instance, 18 November 1952, 9 Revue Egyptienne de Droit International 169 (1953): Egyptian Greek-Orthodox law applies to the marriage between Greek-Orthodox Egyptian and Catholic Italian;

- Cairo Court of First Instance, 6 October 1953, 19 Majallat al-Tashri wa al-Quda 349 (1954): Coptic-Orthodox law applies to the marriage between Greek-Orthodox Greek and Coptic-Orthodox Egyptian;

- Cairo Court of Appeal, 28 December 1955, quoted by Meinhofer, supra n.18 at 112: Coptic-Orthodox law applies to the marriage between Catholic Yugoslavian and Coptic-Orthodox Egyptian;

- Alexandria Court of First Instance, 23 May. 1968, quoted by Sadiq, al-Qanun alDuwali al-Khass: (2) Tanazu' al-Qawanin 129 (1999); Egyptian Maronite-Catholic law applies to the marriage between Maronite Egyptian and a Greek-Orthodox Greek.

24. Elgeddawy (supra n. 3, at 92-96) and Linant de Bellefonds (supra n. 4, at 83941) have argued that, in case of marriage between a foreigner and an Egyptian, Article 14 should be interpreted as referring to the religious law of the Egyptian spouse, without intervention of the internal conflicts rules. 
What is of importance to the argument of this article is that religion is in fact used as a connecting factor, but is never mentioned as such. On the contrary, both the law and legal literature are quite explicit in their limitation of connecting factors to the one of nationality. In other words theory adheres to the (European) model of conflicts rules based on nationality as connecting factor, while practice - i.e. case law - largely adheres to the (Islamic) model of conflicts rules based on religion as connecting factor. It will be demonstrated in the following that the latter is introduced into conflicts law by means of the concept of public policy.

Finally, for the sake of completeness, it should be remarked that parties are not allowed to choose an applicable law, not even if it is Islamic law, notwithstanding its status as prevailing law in matters of personal status. ${ }^{25}$ A prominent Egyptian legal scholar has recently stated that parties may make a choice for an applicable law from among the plurality of Egyptian laws, ${ }^{26}$ but so far the Court of Cassation has twice ruled to the contrary. ${ }^{27}$

\section{Characterization}

Article 10 stipulates that legal concepts in foreign laws (such as domicile, capacity) will be determined and interpreted by the lex fori (qanun al-qadi), i.e. Egyptian law. This interpretation of foreign law is called characterization (qualification in French, takyif in Arabic). But given the plurality of personal status laws in Egypt, according to which of these laws should characterization take place? The majority view holds that this should always be Islamic law in its capacity as the prevailing law in matters of personal status. ${ }^{28}$ Dissenting opinions argue that the Egyptian personal status law which is indicated

25. This has been ruled by the Court of Cassation in several inheritance cases, where application of Islamic law was demanded by foreign heirs (obviously because it was more favourable to the claimant) but the Court ruled in accordance with the conflicts rules for application of the foreign inheritance law. See, e.g., Court of Cassation, Majmu'at al-Ahkam li-Mahkamat al-Naqd, No. 14, Year 37, 9 April 1969; No. 368, Year 33, 24 November 1971.

26. Sadiq, supra n. 23 , at 132 .

27. Court of Cassation, Majmu'at al-Ahkam li-Mahkamat al-Naqd, No. 6, Year 25, 26 June 1956; No. 12, Year 48, 17 January 1979. The Court considered that party autonomy "relates to the distribution of jurisdiction (wilaya) between Islamic law and special laws, which is a matter of the public policy, and any agreement to the contrary is not permissible."

28. 'Abd Allah, supra n. 1, at 183; Fahmi, Usul al-Qanun al-Duwali al-Khass 413 (1985); Salama, supra n. 1, at 393-94; Shawqi, al-Wasit fi al-Qanun al-Duwali alKhass 43 (1991). Also: Alexandria Court of First Instance, 18 October 1950, 6 Revue Egyptienne de Droit International 246ff (1950). Salama argues that application of Islamic law in matters of characterization is, firstly, "easier" for the Egyptian courts, because they have better knowledge of Islamic sources (the judges most often being Muslims - MB), and, secondly, more "logical" because reference to non-Muslim personal status laws will "in most cases" produce results which are incompatible with Islamic law, and finally he argues that as a matter of judicial policy it is better to have one source of reference than several. 
as applicable law by internal conflicts law should serve as a basis for characterization, ${ }^{29}$ or that non-Muslim laws can only be used as a source for characterization with regard to legal concepts which are unknown in Islamic law, ${ }^{30}$ or that characterization of foreign nonMuslim marriages should be based on a comparison with other, similar, foreign laws. ${ }^{31}$

The matter of characterization leads to another complication. All Egyptian personal status laws are religious laws and as such use legal concepts which may be very different from those used in civil laws. This creates a problem in interpreting the conflicts rules of the Egyptian Civil Code itself, which are based on civil law terminology. An example is Article 12, which stipulates that the law of both spouses applies to the "substantive conditions" of the marriage. As one Egyptian scholar has analyzed in depth, Islamic law knows an elaborate set of conditions of marriage but they are almost impossible to match with those used in civil laws. ${ }^{32}$ Another example is the interpretation of the term "financial effects" in Article 13, which is unknown in Islamic law and therefore generally assumed to mean personal as well as financial effects. ${ }^{33}$ Both issues will be further discussed below, in the third paragraph.

\section{Theoretical Framework of Egyptian Public Policy}

In order to come to a proper comparison of Egyptian and European concepts of public policy, a short outline of the general principles of both concepts will be presented in this paragraph. This juxtaposition will already show some of the main differences, and will help to understand the survey of Egyptian case law in the next paragraph.

\subsection{Introduction}

Any legal system allowing for a conflict of law, i.e. allowing for the application of foreign laws by its national courts, will also retain the power to refuse to enforce or recognize rights acquired under for-

29. Ibrahim, supra n. 1, at 210; Kurdi, supra n. 1, at 201; Riyad, supra n. 16 at 203-04; Sadiq, supra n. 23, at 88; Sayyid, al-Wajiz fi al-Qanun al-Duwali al-Khass 434 (1997).

30. 'Abd al-Rahman, supra n. 1, at 240-41.

31. 'Arafa, al-Qanun al-Duwali al-Khass: (2) al-Tanazu' al-Duwali li-l-Qawanin 265 (1993).

32. Musallam, "An al-Shakl wa al-Mawdu' fi Takwin al-Zawaj" 5 Majallat alTashri' wa al-Quda' (1953). 'Abd al-Rahman (supra n. 1, at 322) has also pointed at the differences between Islamic and European civil laws in interpreting the legal consequences of a void marriage.

33. 'Abd Allah, supra n. 10, at 286; 'Abd al-Rahman, supra n. 2, at 323; 'Arafa, supra n. 33, at 282; Fahmi, supra n. 28, at 544-45; Khalid, Mabadi' al-Qanun alDuwali al-Khass 207-08 (1999); Riyad, supra n. 16, at 217; Salama, supra n. 1, at 81112; Shawqi, supra n. 28, at 125. 
eign law. This refusal is based on grounds of public policy, which comprises the fundamental principles of the national legal order. There may be other legal routes to escape the application of foreign law or recognition or enforcement of foreign judgements, but "as contrasted with these other routes public policy may be seen has having the disadvantageous merit of being blatantly frank and obvious." 34

The term public policy in conflicts law in its present technicallegal meaning was first used by European jurists in the middle of the 19 th century. By the end of the 19th century, it was introduced in several national codes (for instance, the Civil Codes of Italy in 1865, Spain in 1888, Germany in 1896). By the 1930s, civil codes all over the world had adopted the term. What constitutes a violation of the legal order is left to the courts. Public policy is therefore only invoked on an ad hoc basis and, consequently, is a notion which is hard to define.

While the use of the term public policy had become almost universal, its interpretation and justification may differ considerably from one country to another. This is not the place to discuss these differences, but there is the matter of terminology to be borne in mind when reading this article. Although written in English and therefore implicitly adhering to a common law vocabulary, it must be emphasized that the subject-matter of this article is based on a civil law terminology. 'This shows in the term public policy, which is a common law term denoting a sense of justice and decency, ${ }^{35}$ and which is different from the civil law term ordre public which is invoked "for moral, philosophical and political reasons, in the large sense of the word." 36 Public policy in common law has assumed far less prominence than the corresponding doctrine in civil law countries, and is therefore not the object of a general legal doctrine as is the case in most civil law countries. ${ }^{37}$ In the following, the term public policy will be used albeit in the meaning of civil law doctrine.

34. Carter, "The rôle of public policy in English private international law," 42 ICLQ 1-2 (1993).

35. Morris, The Conflict of Laws 41 (1984); North \& Fawcett, Cheshire and North's Private International Law 128 (1992).

36. Lagarde, Recherches sur l'ordre public en droit international privé 8 (1959).

37. See for comparison ordre public and public policy, e.g., Dicey, Cheshire and North's Private International Law 88-89 (1993-95); Lloyd, Public Policy. A comparative study in English and French Law (1953); Meinertzhagen-Limpens, "Quelques aspects de l'ordre public en droit comparé," in L'ordre public. Concept et Applications (Romain, 1995), Morris, supra n. 36, at 41, Murphy, "The traditional view of public policy and ordre public in private international law," Georgia Journal of International and Comparative Law 59 (1981); North \& Fawcett, supra n. 36, at 113. One of the reasons for the lesser prominence of public policy in English law is that the English court applies English law in many cases in which conflicts rules of civil law countries allow the application of foreign law. This is in particular the case in matters of personal status. Also, the courts have in the common law system have traditionally more discretionary powers to dismiss actions on the ground of injustice (Dicey, id. at 94, refers to the "residual discretion" of the courts). 
The concept of public policy has developed considerably since the $19^{\text {th }}$ century, but for the purpose of this article it is useful to return to its original definitions. Generally speaking, public policy was considered in two functions. When national rules are deemed to be of such importance that they are to be applied regardless of what conflicts rules may determine as applicable law, these overriding rules of national law are said to be "positive" public policy. Public policy is thus treated as an autonomous connecting factor, like domicile, nationality and place of action. This doctrine, advocated by the aforementioned Mancini in the $19^{\text {th }}$ century, has been abandoned and replaced by more qualified and refined concepts. The Egyptian doctrine of public policy also does not refer to this particular "positive" function, but it will be of relevance when we come to the comparative description of Egyptian public policy.

The function by which public policy is better known, also in Egyptian doctrine, is its "negative" role. When a conflicts rule has designated a foreign rule as applicable law to the case, the court may decide not to apply this rule when it constitutes a violation of the national public policy. European legal literature is unanimous in its opinion that applying public policy is a corrective device of the last resort, not to be applied too easily since it constitutes a deviation from what has been stipulated by the domestic conflicts rules. The court should only reject a foreign law after scrutiny of the law and examination of the actual circumstances of the case.

While the result of both positive and negative public policy is the same - domestic law or concepts are applied in lieu of foreign rules - the essential difference lies in their principle and operation. Negative public policy is the exception to the rule that a foreign law is applicable once it has been assigned by conflicts law; its application should only be denied after due examination of the possible harm its results could cause to the forum's society. Positive public policy, on the other had, does not object to the foreign law per se, but has a priori determined the obligatory adherence to domestic law. The mechanisms of conflicts law, as well as the scrutiny of foreign laws, are of no relevance.

\subsection{General definitions in Egyptian law}

As with conflicts law, Egyptian legal doctrine is indebted to European law with regard to public policy. But in matters of personal status, Egyptian public policy acquires a distinct Islamic character. This is not surprising, given the fact that Islamic law is considered to be the prevailing law in Egypt when it comes to personal status. What is surprising, however, is the omission in the Egyptian legal doctrine to integrate this prominent role of Islamic law into the framework of conflicts law and public policy. For reasons that will be 
discussed later, the Egyptian legal literature sticks - in a quite dogmatic manner - to the civil law concepts. This approach greatly contributes to the puzzling and almost enigmatic forms that Egyptian public policy takes in matters of personal status. Before studying this in more detail, the general definitions of Egyptian public policy as advanced by legislation; case law and legal literature will be examined.

Article 28, the last of the conflicts rules of the Civil Code, reads: "The application of rules of a foreign law, as stipulated in the previous articles, is not allowed if these rules are in contradiction with public policy and morals (al-nizam al-'amm wa al-adab) in Egypt."38 The law itself does not offer any further explanation for the exact meaning of the terms "public policy" and "morals."39 In congruity with European legal doctrine, Egyptian doctrine holds that one of the main characteristics of public policy is its flexibility. It changes with time and place, meaning that public policy in France will be different from Egypt, and public policy in Egypt in 1949 will be different from the one in 2001. In the words of the Explanatory Memorandum:40

"It should be noticed that the notion of public policy is very flexible (marina). (. . .) It is not possible to reject the notion of public policy without also rejecting what is consolidated and established by tradition. It is considered necessary that a place is singled out in the texts of the law for this notion [of public policy], to leave an important outlet through which the social and moral tendencies (tayarat ijtima'iyya wa akhlaqiyya) can find a way into the legal order in order to insert those components of modernity and life ('anasir al-jidda wa al-haya) which it [i.e. the legal order] needs."

The Egyptian Court of Cassation in several of its rulings is more to the point when defining public policy as "the social, political, economical or moral basics in a state related to the highest (or: essential) interest (maslaha 'ulya, or: masalih jawhariyya) of society" 41 or as "the essence (kiyan) of the nation." 42 In the legal literature reference is generally made either to this Court ruling, or to the similar defini-

38. The public policy exception is also mentioned in Articles 135-136, 200, 266 and 551 Civil Code (on, respectively, the subject-matter of a contract, natural obligation, conditions of an obligation, and settlement), Article 298/4 Law of Procedure (on execution of a foreign ruling), and Article 6(2) of Law 462 of 1955 (on internal conflicts law).

39. The relation between public policy and morals (bonnes moeurs in French, morality in English) is equally unclear in most European legal doctrines (see, e.g., Lloyd, supra n. 37 at 5,27 , n. 1; Meinertzhagen-Limpens, supra n. 37, at 224-27).

40. Explanatory Memorandum; supra n. 8, at II: 223.

41. Court of Cassation, Majmu'at al-Ahkam li-Mahkamat al-Naqd, No. 308, Year 29, 25 June 1964; No. 22, Year 34, 7 November 1967; No. 714, Year 47, 26 April 1982; No. 1259, Year 49, 13 June 1983.

42. Court of Cassation, Majmu'at al-Ahkam li-Mahkamat al-Naqd, No. 371, Year 32, 5 April 1967; No. 59, Year 39, 12 February 1975; No. 7, Year 48, 19 January 1977. 
tion presented by the main drafter of the Civil Code, 'Abd al-Raziq alSanhuri:

"The legal principles which are considered to pertain to public policy are those principles that aim at realizing the public interest, from a political, social as well as economic perspective, which [principles] are related to the highest order of society, and supersede the interests of individuals." 43

As in civil law doctrine, the use and interpretation of Egyptian public policy is reserved exclusively for the judiciary. It is the court who must assess "the social and moral tendencies" of society at a given time and place. The notion of public policy is by its very nature so vague that it runs the risk of being misused. The Explanatory Memorandum warned against too personal interpretations:

"The judge should be cautious not to hold his private opinions on social justice to be the general tendency of public policy and morals. He is obliged to apply the general opinion (madhhab 'amm) to which society in its entirety adheres, and not a private individual opinion." 44

In several rulings, the Court of Cassation gave guidelines on how far the concept of public policy may be stretched. When a lower court found an agreement by a foreign company in conflict with Egyptian labor law and consequently ruled it to be in violation of public policy, the Court of Cassation intervened. It warned that public policy should not become a tool in the hands of chauvinist lawyers who might have a preference for their national law "only because it is deemed more useful." ${ }^{25}$ Public policy as meant in Article 28 of the Civil Code, the Court explained, should not be related to mere differences between Egyptian and "foreign values, religious doctrines or politics," but to those rules "which the Egyptian legislature considers to be applicable to foreigners and nationals equally." Even a conflict with Egypt's mandatory rules is not automatically the same as a violation of public policy, because, in the words of the Court, such contradiction does not necessarily mean that the being or essence of Egyptian society is violated. ${ }^{46}$

43. Sanhuri. al-Wasit fi Sharh al-Qanun al-Madani: (I) Masadir al'Iltizam 399 (1964).

44. Explanatory Memorandum, supra n. 7, at II:223.

45. Court of Cassation, Majmu'at al-Ahkam li-Mahkamat al-Naqd, No. 371, Year 32, 5 April 1967.

46. Court of Cassation, Majmu'at al-Ahkam li-Mahkamat al-Naqd, No. 714, Year 47, 26 April 1982; No. 12159, Year 49, 13 June 1983. In both cases the contradiction of an arbitration clause with Article 502/3 of the Code of Procedure was not considered to be a violation of public policy as meant in Article 28 of the Civil Code. See also: Rifa'i, al-Nizam al-'Amm wa al-Tahkim fi al-'Alaqat al-Khassa al-Duwaliyya 13 (1997); Sadiq, supra n. 23, at 206. 


\subsection{Egyptian public policy in matters of personal status}

The concept of public policy as discussed above is very similar to the one in civil law doctrines. The issues on which the Court of Cassation based its rulings, however, are all related to civil matters. Egyptian public policy acquires completely different properties when it deals with matters of personal status. Not "higher interests of society" are the concern of public policy, but the "protection of the rights of the Muslim" (himayat huquq al-muslim). ${ }^{47}$ This use of public policy has two consequences which set it apart from its counterpart in Europe. First, as will be shown in the next paragraph, it aims at preserving not general principles, but substantive rules of Islamic law. The imposition of these rules as a matter of public policy without further scrutiny of the foreign rules they substitute is reminiscent of public policy in its positive sense. Secondly, it introduces religion as a connecting factor in Egyptian conflicts law. Or to be more specific: not religion as such is the connecting factor, but the religion of Islam, because of this particular use of public policy as the protector of Muslims' interests only. From the case law it appears that (the Islamic) religion as a connecting factor only became a general rule of public policy during the $1950 \mathrm{~s} .{ }^{48}$

\section{"Islamic" and "general" public policy}

Defining public policy as a means to safeguard the "rights of Muslims" contradicts the Court of Cassation's definition mentioned earlier of safeguarding the interests of the entire nation. In matters of personal status law, however, there is the problem of plurality of religious codes. Which of the many - often contradictory - princi-

47. 'Arafa, supra n. 33, at 272; 'Abd Allah, supra n. 10, at 253, 304, 342; Ibrahim, supra n. 1, at 220; Fahmi, supra n. 28, at 540, 548; Khalid, supra n. 33, at 254; Riad, Fuad, and Hisham Alil Sadiq, "Les conflits de lois en droit interne et en droit international privé égyptien dans les matières de statut personnel," in Le statut personnel des musulmans 74 (Carlier/Verwilghen, 1992); Sadiq, supra n. 23, at 276-77; Sultan, "Fi al-'Awamil alati ta'taridu Qanun al-Mirath fi al-Tatbiq," 1 Majallat al-Qanun wa alIqtisad 227 (1948); 'Abd al-Wahab, "al-Nizam al-'Amm fi al-Ahwal al-Shakhsiyya fi Masr," al-Muhamah 201 (1958). In the words of 'Abd Allah (idem): "the enjoyment by the Muslim of the rights which have been accorded to him by the Islamic Shari'a, pertains to public policy."

48. To my knowledge, the latest cases in which the court stated explicitly that the connecting factor of Egyptian conflicts law in matters of dissolution of marriage was based on nationality, not religion, were those of the Mixed Court of Appeal, 6 June 1947 (quoted in 'Abd al-Wahab, supra n. 47, at 198), and the Alexandria Court (9 April 1951, 7 Revue Egyptienne de Droit International 194 (1951)). The courts declared that the law applicable to the divorce of an Italian husband who had converted to Islam was not Islamic law, but Italian law. The commentary to the Alexandrian ruling mentions that this ruling was in accordance with Egyptian case law until then, as well as the intention of the Egyptian legislature when drafting the new Civil Code. In his article dated 1960, Linant de Bellefonds (supra n. 4, at 831) held a similar view, denouncing the use of public policy which grants foreign Muslim husbands the right of Islamic divorce as a "distortion of the concept of public policy." 
ples of these codes should serve as public policy when dealing with foreign laws? The options are then to either construct a neutral and national public policy, or to select the principles of one of these codes as the national public policy. Egyptian conflicts law has made a choice for the latter: Islamic law is the source of public policy because it is the prevailing law in matters of personal status as well as the law of the large majority of Egyptians. ${ }^{49}$ The choice was halfhearted, however, because public policy is being applied only to foreign laws when the foreigner involved is Muslim. The very same foreign rules will not be considered a violation of the same public policy when the person involved is a non-Muslim foreigner. Only very few issues are considered to constitute a violation of Egyptian public policy irrespective of the religion of the person involved, such as legal impediments based on race or color. In order to make the distinction between these two scopes of Egyptian public policy I suggest to refer to "Islamic" public policy when it pertains to Muslim foreigners only, and "general" public policy when it pertains to all foreigners, Muslim as well as non-Muslims. Now that the occurence of "general" public puolicy is a rare event, we'll focus on the "Islamic" public policy.

\section{Islamic public policy and "Islamic law"}

In the Egyptian legal literature and case law it is commonly said that a foreign rule which is set aside by Islamic public policy will be substituted by "Islamic law" (alShari'a al-islamiyya). This is confusing, because there is a difference between Islamic law and its vast corpus of jurisprudence ( $f i q h$ ) and those rules of personal status law which have been codified by the Egyptian legislature during the $20^{\text {th }}$ century. ${ }^{50}$ These codifications may be considered "Islamic law," but the fact remains that they contain additions or changes which are different or even contradictory to the doctrines of Islamic law. ${ }^{51}$ When the courts and legal literature mention the application of Islamic law in this respect, do they mean Egyptian (codified) personal status law for Muslims, or Islamic personal status law as contained in the fiqh? Egyptian legal doctrine does not provide an answer, but, when specifically asked in an interview, two prominent Egyptian

49. Court of Cassation, Majmu'at al-Ahkam li-Mahkamat al-Naqd, Nos. 16 and 26, Year 48, 17 January 1979.

50. Egyptian personal status law in matters of marriage and divorce is codified in Laws No. 25 of 1920, No. 25 of 1929, No. 100 of 1985 and No. 1 of 2000 . Guardianship is codified in Laws Nos. 118 and 119 of 1952, family name, family ties and legal capacity in the Civil Code of 1949, and inheritance laws in Laws No. 77 of 1943 and No. 71 of 1946. All matters not covered by these laws are to be dealt with in accordance with "the prevalent opinion of the Hanafi doctrine" (Article 280 of the Decree on the Organisation of the Shari'a Courts).

51. For instance, Article $11 \mathrm{~b}$ of Law No. 25 of 1929 allows the woman to request divorce from her husband when he enters into a second marriage, and Article 20 of the new Law No. 1 of 2000 allows for an enforcement of a $k h u l^{\prime}$ divorce by the court against the will of the husband. 
scholars of conflicts law confirmed that Egyptian Muslim personal status law is meant. ${ }^{52}$ Most probably, however, the use of the term "Islamic law" is preferred for reasons" of its metaphysical authority, as well as for the fact that the rules that constitute Islamic public policy are more often found in the fiqh than in the Egyptian codified Muslim personal status law. In the following, I will refer with the term Islamic law to both Egyptian (codified) personal status law for Muslims and the additional rules as contained in the fiqh.

Now that the range of "Islamic law" in Egyptian public policy is clarified, we need to examine which rules of Islamic law constitute this public policy. A comprehensive survey of these rules will be presented in the next paragraph. Suffices it here to give a general definition of these rules. Islamic public policy, in short, comprises those rules which are considered essential rules of Islamic law. This essential character is not so much related to content but to the source of the rule. Essential are the rules which are based on "irrefutable texts" (nusus qatica), signifying those Islamic religious-legal texts which have undeniable authority. ${ }^{53}$ Prime example is the Quran: the legal rules which are mentioned in this sacred text (such as polygamy, unilateral divorce, inheritance shares) are essential and irrefutable rules of Islamic law par excellence. It is for that reason that these rules are considered inalienable rights for Muslims that may not be waived or altered. ${ }^{54}$ Also, the indisputability of the source of these rules presupposes an equal strong conviction of the believer regarding the correctness of the content of this rule. The closer the rule is to its divine source, the more the rule is considered right and just. In the words of the Court of Cassation when it ruled that Islamic inheritance law pertains to public policy:

"Rules of [Egyptian] inheritance law are derived from irrefutable texts of Shari'a law; which are [. . .] considered to pertain to public policy in Egypt due to their strong link to the legal and social order which is deeply rooted in the conscience of society (damir al-jama'a) insofar that general feelings would be hurt (yata'adhdha al-shu'ur al-'amm) if it were not adhered to." 55

The foregoing has the following practical implications. First, Islamic public policy does not set the entire foreign law aside, but only

52. Interview conducted by the author with the professors of international private law Ibrahim Ahmad Ibrahim of the University of Ayn Shams, (interview on 3 May 2000) and Ahmad 'Abd al-Karim Salama of the University of Helwan (interview on 8 May 2000).

53. Court of Cassation, Majmu'at al-Ahkam li-Mahkamat al-Naqd, No. 17, Year 32, 27 May 1964; No. 10, Year 48, 20 June 1979; No. 85, Year 63, 2 January 1997. See also: 'Abd Allah, supra n. 10, at 340.

54. See, e.g., Rifa'i, supra n. 47, at 14; Sanhuri, supra n. 43, at 410.

55. See rulings in $\mathbf{n} .54$. 
those foreign rules which are deemed a violation of essential rules of Islamic law will be substituted by the rules of Islamic law. ${ }^{56}$ For instance, when the wife of a Greek couple converted to Islam and demanded divorce from her husband, the Court of Cassation applied Islamic law to the divorce but Greek law to the custody (hadana) of the children. ${ }^{57}$ Second, it should be pointed out that, in addition to the application of Islamic law to Muslims by virtue of public policy, Islamic law may still be applicable to a foreign non-Muslim. But this is a matter of internal conflicts law rather than public policy. This is the case when the non-Muslim foreigner is married to a non-Muslim Egyptian and both spouses belong to a different religion, rite or sect (see above, 1.2). And in case of inheritance, the Egyptian (Islamic) law of succession applies to all Egyptians, regardless of their religion, and therefore also to the non-Muslim foreigner when he is heir to the inheritance of a deceased non-Muslim Egyptian, or when the property of the deceased non-Muslim foreigner is located in Egypt (see below, section 3.5).

\section{Cases of Public Policy}

In this paragraph, a survey will be presented of all the issues related to public policy in Egyptian conflicts law regarding personal status. For this purpose, the entire case law of the Court of Cassation since the Civil Code has come into effect in 1949 has been examined, as well as most Egyptian legal literature and the case law of the lower courts insofar as referred to by the literature. In the following paragraphs the picture will emerge of what is considered essential to the legal order of Egyptian personal status law, and, consequently, what are considered essential rules of Islamic law. It should be noted that the issues discussed in this paragraph are not comprehensive since they deal only with cases that have been brought before the court. Future court cases may very well provide additional material or amend existing views. Also, some issues have not been dealt with in court, but are mentioned in the legal literature. Moreover, some rules are unanimously referred to as public policy, while the other rules appear to be minority's opinion.

Both the courts and the legal scholars refer to public policy without further specifications like "positive" or "negative" or otherwise, and in several instances Western legal doctrine would deem the term public policy not even applicable. In the following cases I will use the word "public policy" without further qualification, in imitation of the

56. The startled observation of Linant de Bellefonds (supra n. 4, at 831) that public policy has the effect of substituting the national law of a foreign convert entirely by Islamic law is therefore not correct.

57. Court of Cassation, Majmu'at al-Ahkam li-Mahkamat al-Naqd, No. 76, Year 53, 27 January 1987. 
Egyptian literature and case law, and will leave further discussion on the meaning of this term to paragraph 4 below.

\subsection{Validity of marriage}

According to the Egyptian conflicts rules of the Civil Code, the lex loci celebrationis applies to the formal conditions of the marriage (Article 20), while both the national laws of the spouses apply to the substantive conditions for the validity of the marriage (Article 12). The terms substantive and formal conditions are taken from the civil law tradition, and, as mentioned before, cause the Egyptian legal scholars considerable difficulty to interpret since the source of characterization - Islamic law - does not use these two conditions. The legal literature unanimously agrees, however, that most issues of public policy relate to the substantive conditions of a marriage.

Marriage of Muslim woman with non-Muslim man

The marriage of a Muslim woman with a non-Muslim man will constitute a violation of Egyptian public policy. This marriage impediment is not codified in Egyptian law, but is adhered to as a rule of Islamic law which considers such marriage prohibited (haram) and void, as mentioned in the Quran. ${ }^{58}$

The marriage between a Muslim woman and a non-Muslim man being an infringement of public policy has been upheld in several rulings of the Court of Cassation dealing with mixed religious marriages of Egyptian nationals. ${ }^{59}$ The case law of lower courts ${ }^{60}$ as well as the legal literature ${ }^{61}$ unanimously agree that this marriage impediment also applies if both spouses have a foreign nationality, with a marriage validly concluded abroad, and Egyptian conflicts law deeming foreign law applicable to that marriage. Whether the woman was already Muslim when she got married, or converted to Islam during

58. Quran, II:221 and LX:10.

59. Court of Cassation, Majmu'at al-Ahkam li-Mahkamat al-Naqd, No. 28, Year 33, 9 January 1966; No. 16, Year 35, 8 March 1967; No. 9, Year 44, 24 December 1975; No. 61, Year 56, 29 March 1988; Nos. 475, 478, 481, Year 65, 5 August 1996.

60. To my knowledge, the Court of Cassation has so far not ruled in cases of foreign couples with a non-Muslim husband and a Muslim wife. Examples of rulings by lower courts declaring such marriages void are those of the Cairo Court of First Instance (unpublished, quoted by 'Abd Allah, supra n. 10, at 253):

- No. 30, Year 1953, 6 October, 1953 (Turkish woman and British man);

- No. 128, Year 1950, 13 May 1952 (Palestinian woman and British man);

- No. 130, Year 1952, 12 February 1952 (Greek couple);

- No. 143, Year 1952, 28 October 1952 (British couple);

- No. 140, Year 1951, 17 December 1951 (British couple).

61. 'Abd Allah, supra n. 10, at 253; 'Abd al-Rahman, supra n. 1, at 299, 302; 'Arafa, supra n. 31, at 271; Fahmi, supra n. 28, at 540; Ibrahim, supra n. 1, at 219; Riyad, supra n. 16, at 208; Sadiq, supra n. 23, at 277; Salama, supra n. 1, at 609, 78081,856 ; Sayyid, supra n. 29, at 443, Shawqi, supra n. 28 , at 121,443 ; 'Abd al-Wahab, Mudawwana al-Ahwal al-Shakhsiyya li-ghayr al-Muslimin al-Masriyin wa al-Ajanib 138 (1959). 
her marriage makes no difference (see for conversion below, 3.6). Some authors even argue that the nationality obtained by a Muslim woman through her marriage with a non-Muslim man should not be recognized by the Egyptian courts. ${ }^{62}$

Several authors have argued that the prohibition of such marriage is based on internal conflicts law rather than public policy. They advance a legal-technical approach: the conflicts rule of Article 14 stipulates that Egyptian law is applicable to that marriage, and Islamic law as Egyptian prevailing law in matters of personal status declares such marriage null and void. ${ }^{63}$ According to this opinion, the nullity of a mixed marriage consequently is not of public policy but of internal law. I have argued elsewhere that even within Egyptian internal law the nullity of such mixed marriages is a matter of public policy. ${ }^{64}$

When discussing this issue, the Egyptian legal literature usually makes the sidestep to the reverse case of the Islamic marriage impediment mentioned above: a Muslim man may marry a non-Muslim woman. In the legal literature it is said that, if a foreign law were to prohibit this latter marriage, then Egyptian public policy would also interfere but this time to declare the foreign impediment null and void and the marriage valid. ${ }^{65}$

\section{Polygamy}

The polygamous marriage (or more exact: the polygynous marriage, because it is the Muslim man who has the exclusive right to marry up to four wives simultaneously) is unanimously referred to by the legal literature as a rule endorsed by Egyptian public policy in marriages involving foreign Muslim husbands. ${ }^{66} \mathrm{~A}$ foreign law prohibiting a Muslim man to conclude a valid second (or third or fourth) marriage will be deemed in violation of Egyptian public policy, and the Egyptian court will allow a male Muslim foreigner to enter into a polygamous marriage, regardless of any impediments to that extent in his national law: ${ }^{67}$ The reason for the public policy nature of the polygamous marriage must be sought in its explicit per-

62. This matter is discussed by 'Abd al-'Al, al-Ittijahat al-Haditha fi Mushkila "Tanazu 'al-Jinsiyat" (1997).

63. 'Abd Allah, supra n. 10, at 257, n. 3; Sadiq, supra n. 23, at 277.

64. Berger, supra n. 17, at 24 .

65. See literature mentioned in footnote 62 .

66. 'Abd Allah, supra n. 10, at 253, 'Abd al-Rahman, supra n. 1, at 303; 'Arafa, supra n. 31, at 272; Ibrahim, supra n. 1, at 220; Sadiq, supra n. 23, at 277; Fahmi, supra n. 28, at 540; Rifa'i, supra n. 46, at 14; Riyad, supra n. 16, at 208; Salama, supra n. 1, at 780-81; Sayyid, supra n. 29, at 443; Shawqi, supra n. 28 , at 121 .

67. The Court of Cassation to my knowledge has so far not ruled in such cases. The Cairo Court of First Instance ruled on 5 January 1954, 19 Majallat al-Tashri wa al-Quda 357 (1954) that as a matter of public policy the second marriage by a Muslim of British nationality was no reason for his first.wife of Greek nationality and Christian faith to obtain a court order of nullity of that second marriage. 
mission by the Quran. ${ }^{68}$ This also has its reverse effect: any waiver or amendment of this right by a Muslim man or any third party will be void by being a violation of public policy. ${ }^{69}$

\section{Other substantive conditions}

The status of some substantive conditions is unclear, such as the marriage impediments of the waiting period of the wife ('idda) after divorce or decease of her husband, and the relatives with whom marriage is not allowed (maharim). Do these impediments apply to foreigners at all, and if so, to all foreigners or only to Muslims? There is no case law on this matter. Although both marriage impediments are mentioned in the Quran, ${ }^{70}$ one may deduct from the few references in the legal literature that the 'idda applies to Muslim foreigners only, and the forbidden relations to all foreigners regardless of their religion. ${ }^{71}$

A similar ambiguity surrounds the bridal gift (mahr) which the Muslim groom has to pay to the bride as part of the marriage contract. It is a condition for the validity of the marriage contract, imposed by the Quran itself. ${ }^{72}$ Again there is no case law available and the legal literature only occasionally refers to this obligation, but never in terms of public policy. ${ }^{73}$ Being a Quranic as well as substantive condition might point to the conclusion that obligation indeed pertains to Islamic public policy. On the other hand, the omission of such reference in the legal-literature might also be taken as a sign to the contrary.

Consent and witnesses: public policy?

Although not endorsed by the Quran, Islamic law stipulates mutual consent (taradi) between bride and groom and the presence of two male Muslim witnesses (shahada) as the two constitutive condi-

68. Quran, IV:3. Polygamy is allowed by the Egyptian Muslim personal status law, which demands that the first wife (or wives) is to be informed of the next marriage of her husband (Articles 11bis and 22bis of Law No. 25 of 1929).

69. Rifa $i$, supra n. 46 , at 14 . The contractual obligation by the husband that he will not marry a second wife has therefore no legal effect. It is allowed, however, for a couple to stipulate in their marriage contract that her marriage with him will be dissolved if he enters into a second marriage.

70. Quran, II:228 ('idda) and IV:24 (maharim).

71. 'Abd Allah (supra n. 10 at 255) and Salama (supra n. 1, at 780) mention the 'idda as public policy rule for Muslim foreigners only. 'Abd al-Rahman (supra n. 1 at 302), Salama (idem) and Shawqi (supra n. 28, at 440) mention forbidden relations as public policy for all foreigners, while "Abd Allah (idem) confines this rule to Muslim foreigners.

72. Quran, IV:4 and XXXIII:50. The obligation to pay the bridal gift is not codified in Egyptian Muslim personal status law, except for a rule on the burden of proof regarding its amount (Article 19 of Law No. 25 of 1929).

73. 'Abd Allah, supra n. 10, at 286, 'Abd al-Rahman, supra n. 1, at 312, Musallam, "Batlan al-Zawaj wa Inhilalu-hu fi Qawa'id al-Isnad al-Masriyya wa fi al-Qanun alMawdưi al-Muqarin," 1 Majallat al-Qanun wa al-Iqtisad 260 (1960). 
tions to conclude a valid marriage. ${ }^{74}$ The legal literature considers mutual consent to be a substantive condition (i.e. the national laws of both spouses are applicable - Article 12), while a majority is of the opinion that the presence of witnesses is a formal condition (i.e. the lex loci celebrationis applies - Article 20). ${ }^{75}$ It is unclear, however, whether these conditions pertain to public policy. There is no case law on this subject and the Egyptian legal literature answers affirmative only with regard to Egyptian Muslims who marry abroad. To my knowledge, only four authors confirmed that these two conditions apply also to the marriages of Muslim foreigners which have been validly celebrated in their own country. ${ }^{76}$ If this is the case, the following observations can be made. Whether the marriage ceremony of Muslim foreigners is celebrated in a religious format or not is of no importance: a civil marriage can be recognized because it always requires mutual consent as well as the presence of witnesses (provided they are male and Muslim). ${ }^{77}$ A church marriage, on the other hand, even in the presence of Muslim witnesses will not be recognized because it is the religious authority that actually concludes the marriage, the witnesses being of no legal relevance. ${ }^{78}$ If the foreign country does not have an institution like a civil marriage, the Muslim abroad can resort to the so-called 'urfi marriage, which requires only the fulfillment of these two conditions. ${ }^{79}$

\subsection{Mutual obligations of spouses}

The conflicts rule of Article 13/1 stipulates that the national law of the husband governs the "financial" effects of the marriage. As observed above, the legal literature has interpreted this article to the extent that "financial effects" comprises both the personal effects (i.e. mutual rights and obligation between spouses) and the matrimonial property effects.

74. The term "Islamic marriage" is misleading because a marriage according to Islamic law is actually a civil marriage, without the requirement of any sacred or liturgical ceremony or intervention by religious authorities.

75. 'Arafa, supra n. 31, at 269; Fahmi, supra n. 28, at 540; Ibrahim, supra n.1, at 211; Khalid, supra n. 33, at 191; Riyad, supra n. 16, at 203, 214; Sadiq, supra n. 23, at 270; Salama, supra n. 1, at 784-85; Shawqi, supra n. 28, at 440 . A few authors argue that the presence of witnesses also constitutes a substantive condition: 'Abd Allah, supra n. 10, at 262-63; Musallam, supra n. 74, at 265; Shawqi, supra n. 28, at 120.

76. Ibrahim, al-Qanun al-Duwali al-Khass: (1) al-Tanazu' al-Qawanin 220 (1999), Sayyid, supra n. 29, at 443; Shawqi, supra n. 28, at 443 and Salama, supra n. 52.

77. 'Arafa, supra n. 31, at 278; Ibrahim, supra n. 1, at 220; Salama, supra n. 1, at 791-93; Shawqi, supra n. 28, at 124. Khalid, supra n. 33, at 189; Musallam, supra n. 32 , at 10 and Riyad, supra n. 16, at 214 represent the minority view that witnesses are not required as long as the civil marriage is publicly announced.

78. Id.

79. 'Abd al-Rahman, supra n. 1. at 310, 'Arafa, supra n. 31, at 278; Musallam, supra n. 32, at 29; Salama, supra n. 1, at 791-93. 
According to Islamic law, the wife's obligation of obedience ( $t a^{\prime} a$ ) towards her husband is probably the most essential of her marital obligations. $^{80}$ In Egyptian Muslim personal status law it implies among others that the husband has the right to prevent his wife to leave the house or to work, except under certain conditions (such as the social standing of the woman) or when the reasons for leaving the house need no permission from the husband (such as visiting the mosque or relatives). ${ }^{81}$ The wife is not held to her duty of obedience if the husband does not fulfill his reciprocal marital obligation of maintaining his wife during their marriage, meaning all financial obligations related to marriage (nafaqa). ${ }^{82}$ Egyptian Muslim personal status law mentions in a non-limited way food, housing, clothing and medical expenses. ${ }^{83}$

Are these rights so essential to Egypt's legal order that they pertain to public policy? They do indeed pertain to Egypt's internal public policy in the sense that these rights cannot be waived or amended, ${ }^{84}$ but it is not clear whether this public policy also extends to foreigners in general or Muslim foreigners in particular. Except for the husband's obligation of maintenance, ${ }^{85}$ these issues have not arisen in case law and are hardly discussed in the legal literature. Given the fact that these obligations are stipulated by the Quran, it may be argued that they are at least incumbent on Muslim foreigners. A prominent scholar has asserted that both obligations do indeed pertain to public policy but he does not make the specific provision that this public policy applies to Muslims only, implying that all foreigners, regardless of their religion, are subject to this rule. ${ }^{86}$ This could be justified with the fact that these mutual obligations are not typical for Islamic law but feature in many other laws, including most Egyptian personal status laws for non-Muslims.

\subsection{Children}

\section{Illegitimate children}

In Egypt, children born out of wedlock (zina) or out of voidable marriages cannot be acknowledged by the biological father. This is a rule of Islamic law and as such considered to be a rule of public policy by both the Court of Cassation and the legal literature. ${ }^{87}$ The draft

80. Quran, II:228.

81. Article 1/4 of Law No. 25 of 1920 and Article 11bis/2 of Law No. 25 of 1929.

82. Quran, II:233, and LXVII:6.

83. Articles 1-2 of Law No. 25 of 1920 and Articles $16 \mathrm{ff}$. of Law No. 25 of 1929.

84. Rifa'i, supra n. 46, at 14 ; Sanhuri, supra n. 43 , at 410.

85. Court of Cassation, Majmu'at al-Ahkam li-Mahkamat al-Naqd, No. 31, Year 15, 10 January 1946: the Muslim husband of an English couple was obliged to pay maintenance.

86. Salama, supra n. 1 , at 606,826 .

87. Salama, supra n. 1, at 891, 897; 'Arafa, supra n. 31, at 264. The exception to the rule is that an illegitimate child is recognized as legal heir of the mother. 
law of the Civil Code contained a conflict rule regarding filiation (banuwa) out of wedlock (called "natural filiation"), but this was not taken over by the final version of the Civil Code. ${ }^{88}$ The question therefore arises whether this should be interpreted as a refusal to accept foreign "natural filiations." The Court ruled that a foreign judgement establishing parentage will be recognized in Egypt under certain circumstances, one of them being that "it should not violate Egyptian public policy, bearing in mind that Islamic law considers the illegitimate child excluded from inheritance and parentage." 89 The wording of this ruling appears to limit this rule of public policy to Muslim foreigners.90 The opinion that this rule of public policy applies to all foreigners, regardless of their religion, appears to be a minority view. ${ }^{91}$

Adoption

Adoption (tabanni) is forbidden in Islamic law. For that reason it is assumed that it is also not allowed under Egyptian law, which does not contain any rules on the subject. Egyptian law does provide, however, conflict rules regarding adoption, albeit not in the Civil Code but in the Code of Procedure (Articles 911-918). According to these rules, adoption is permitted when the laws of both the adopter and the adoptee allow adoption. ${ }^{92}$ This leads some scholars to conclude that foreign laws allowing adoption are not contradicting Egyptian public policy if they fulfill this condition, ${ }^{93}$ while others argue that adoption is always a violation of public policy if it involves a Muslim. ${ }^{94}$ The latter opinion might be assumed to be the prevalent one given the fact that adoption is in so many words prohibited by the Quran itself.95.

\subsection{Divorce}

According to the conflicts rule of Article 13/2, the national law of the husband governs dissolution of the marriage and its effects, being by unilateral divorce (talaq), judicial divorce (tatliq) or corporal separation (infisal). In Islamic law, the husband and wife have different rights of divorce, and public policy treats them differently as well.

88. Explanatory Memorandum, supra n. 7, at I:261.

89. Court of Cassation, Majmu'at al-Ahkam li-Mahkamat al-Naqd, No. 4, Year 25, 12 January 1956.

90. Also Salama, supra n. 1 , at 898 .

91. 'Arafa, supra n. 31, at 309.

92. For example, an Italian widow was allowed to adopt a Greek boy, both of whom were born and domiciled in Alexandria (Alexandria Court of First Instance, 3 February 1953, 9 Revue Egyptienne de Droit International 156 (1953)).

93. 'Abd Rahman, supra n. 1, at 256; 'Arafa, supra n. 31, at 310-311; Ibrahim, supra n. 1, at 269-71; Shawqi, supra n. 28, at 248).

94. Salama, supra n. 1, at 902, 909.

95. Quran, XXX:4-5. 
Divorce by the husband

Islamic law grants the Muslim husband the right of unilateral divorce, which means that he may divorce his wife at will, without the intervention of third parties or a judicial institution. ${ }^{96}$ According to the legal literature, the unilateral divorce is another standard example of (Islamic) public policy: a Muslim foreign husband will be granted his right of unilateral divorce by the Egyptian courts, regardless of what his national law stipulates in this respect. ${ }^{97}$ This rule of Islamic public policy is also applied by the courts. ${ }^{98}$ Like polygamy, the right of unilateral divorce can not be waived or amended.99

Divorce by the wife

The divorce rights of the Muslim women are not protected by public policy. A foreign Muslim woman who has no or very limited possibilities of divorce under her national law, can not appeal to Egyptian public policy in order to be granted the divorce rights as enjoyed by Egyptian Muslim women. It must be assumed that the reason lies in the fact that women's divorce rights are not mentioned in the Quran, but were developed by Muslim legal doctrine. The only divorce right granted to the woman by virtue of public policy is when she has converted to Islam and her husband remains non-Muslim. Public policy in that respect is not related to the divorce itself, however, but to the forbidden marriage between a Muslim woman and a non-Muslim man.

\section{Prohibition of divorce}

Foreign laws which outright deny the right of divorce (as used to be the case, for instance, in those countries in the times when divorce law was based on Catholic law) are occasionally mentioned in the Egyptian legal as a violation of Egyptian public policy. Divorce, it is argued, is an essential freedom of the individual. ${ }^{100}$ This point of view, however, is in contradiction with the fact that the prohibition of

96. Quran, II:227-232. These rules of divorce was codified in Egyptian Muslim personal status law in Articles 1 to 4 of Law 25 of 1929.

97. 'Abd Allah, supra n. 10, at 253; 'Arafa, supra n. 31, at 294; Fahmi, supra n. 28, at 548; Ibrahim, supra n. 1, at 220; Khalid, supra n. 33, at 227; Rifa'i, supra n. 46, at 14; Riyad, supra n. 16, at 237; Sadiq, supra n. 23, at 298; Salama, supra n. 1, at 856; Shawqi, supra n. 28 , at $131,457$.

98. The Cairo Court of First Instance ruled in two cases that Muslim Turks as a matter of public policy had the right of talaq, even though the Turkish (secular) law did not recognize such divorce: No. 149, Year 1952, 17 March 1953 and No. 66, Year 1955, 5 March 1957 (both unpublished, quoted by 'Abd al-Wahab, supra n. 47, at 203. Similar rulings can be found in case law dealing with foreigners who have converted to Islam. This will be discussed in paragraph 3.4.

99. Rifa'i, supra n. 46, at 14; Sanhuri, supra n. 43 , at 410 . The husband is allowed, however, to assign his right of divorce to his wife.

100. Riyad, supra n. 16 , at 236 . 
divorce stipulated in Catholic laws has always been upheld by the Egyptian courts in cases involve Catholic Egyptians. ${ }^{101}$

\subsection{Law of succession}

Islamic succession law is not only considered one of the most outstanding achievements of Islamic legal science, but is also the part of Islamic law with a particularly strong religious significance, mainly for the reason that it is largely based on numerous Quranic provisions. Both the Egyptian Law of Intestate Succession and Law of Testament are directly derived from Islamic law, although with some significant amendments. ${ }^{102}$ Both laws apply to Muslim as well as non-Muslim Egyptians, which is an exception to the rule of non-Muslim legal autonomy in the field of personal status law. ${ }^{103}$ With regard to foreigners, the conflicts rule of Article 17 stipulates the application of the national law of the deceased or the testator.

\section{Intestate succession}

If one were to take the rulings of the Court of Cassation literally, Islamic intestate succession law should be considered a public policy law in its entirety, excluding any other law.

"The rules of [Egyptian] succession law are derived from irrefutable texts (nusus qati'a) in Shari'a law, which, as a right of Muslims, are considered to pertain to public policy in Egypt, and application of the rules of another law are therefore not possible if they contradict this law."104

However, this ruling needs some interpretation. First, which "other law" will be excluded from application by public policy? The mentioned case law of the Court of Cassation usually refers to the full exclusion of the inheritance laws of the non-Muslim Egyptian communities. In addition, in the Egyptian legal literature the operation of this public policy is limited to the national law of a foreigner who is Muslim ${ }^{105}$ - implying that public policy does not apply to that very same law when the foreigner involved is not Muslim.

101. Berger, supra n. 17, at 122

102. Intestate Succession Law, Law No. 77 of 1943 (Qanun al Mirath) and Law of Bequest, Law No. 71 of 1946 (Qanun al-Wasaya). See for detailed discussion of the Egyptian amendments: Coulson, Succession in the Muslim family (1971).

103. Articles 875 and 915 Civil Code.

104. Court of Cassation, Majmu'at al-Ahkam li-Mahkamat al-Naqd, No. 17, Year 32, 27 May 1964; No. 10, Year 48, 20 June 1979; No. 85, Year 63, 2 January 1997. Compare Coulson supra n. 102 at 4: "[. . . ] it constitutes such an integral and deeprooted part of the religious ethic."

105. Court of Cassation, Majmu'at al-Ahkam li-Mahkamat al-Naqd, No. 17, Year 32, 27 May 1964; 'Abd Allah, supra n. 1, at 398 and supra n. 10, at 340, 342 (the conclusion by Linant de Bellefonds, supra n. 4, at 855, that 'Abd Allah in an article in 1954 had voiced the opinion that none of the rules of islamic succession law constituted a rule of public policy, must be considered inaccurate in the light of 'Abd Allahs 
Then there is the matter of what the effect of public policy will be to the national law of the Muslim foreigner. Although the Court implies in its rulings that his entire national law will be substituted by (Egyptian) Islamic succession law, it is generally assumed that the public policy character only refers to certain rules of this law. ${ }^{106}$ There is general consensus in the legal literature on at least four rules which have a public policy character: a) the share of the woman is half of her brother's, b) the order of precedence of the relatives assigned as heirs by the Quran, c) the size of each of the shares allotted by the Quran, and d) the prohibition of intestate succession between a Muslim and non-Muslim. ${ }^{107}$ Hence, the foreign law which allots the female heir a share equal to her brother's, or excludes the spouse, or allots the heirs shares which are different in size than stipulated by Islamic law, will be considered a violation of public policy, but only when the case involves a Muslim. Consequently, not the entire foreign law, but only that specific rule will be replaced by the relevant rule of Islamic law. With regard to the Islamic prohibition of intestate succession between Muslims and non-Muslims, the consequence of this public policy rule is the exclusion of the heir - whether Muslim or non-Muslim - and the full application of the law of the deceased (whether Egyptian or foreign). ${ }^{108}$

\section{Testamentary succession}

According to Islamic law, the will (wasiya) is the sole possibility for Muslims and non-Muslims to succeed to each other's properties. The only limitation is that the testator may not bequeath more than

subsequent writings); Fahmi, supra n. 28, at 514; Ibrahim, supra n. 76, at 294; Khalid, supra n. 33, at 254; Sadiq, supra n. 23, at 328; Salama, supra n. 1, at 949; Sayyid, supra n. 29, at 401; Shawqi, supra n. 28, at 155; Sultan, supra n. 47, at 277. There are a few dissenting albeit opposing opinions. One is presented by 'Arafa, supra n. 31, at 328-29 who argues that certain Quranic rules of succession should also apply to non-Muslims. The opposing view is taken by Riyad, supra n. 16, at 280-81 and Zaki, "Mawarith al-ra'aya al-Atrak fi Masr," Majallat al-Qanun wa al-Iqtisad (1948) who argue that differences between foreign law and Islamic law should not constitute a violation of public policy because such difference "does not affect Egyptian society."

106. This issue has been extensively discussed in the 1940 s and 1950 s, due to the many inheritance cases of Muslim Turks whose national law is a secular law. The Egyptian Supreme Shari'a Court (since 1956 merged into the Court of Cassation) at first ruled that Turkish law should in its entirety be substituted by Islamic law, but later applied the Turkish law in a modified form (see, e.g., Zaki, idem).

107. 'Abd Allah, supra n. 10, at 340-43, 'Arafa, supra n. 31, at 327-29; Ibrahim, supra n. 1, at 385-88 and n.78 at 337; Sadiq, supra n. 23, at 328; Salama, supra n. 1, at 605, 947-49; Sayyid, supra n. 30, at 399; Shawqi, supra n. 29, at 164, 256).

108. 'Abd Allah, supra n. 11, at 339, 'Arafa (193:237), Ibrahim, supra n. 2, at 290; Khalid, supra n. 34, at 254; Salama, supra n. 2, at 947; Shawqi, supra n. 29, at 159. The Court of Cassation has in several rulings excluded foreign Christian heirs from the inheritance when it became clear that the deceased had converted to Islam: Majmu'at al-Ahkam li-Mahkamat al-Naqd, No. 28, Year 45, 1 March 1978; No. 10, Year 48, 20 June 1979. 
one third of his property. The remaining two thirds (or more, of course) are to be divided according to the rules of intestate succession law.

As with intestate succession, public policy pertains to Muslims only. However, testamentary succession does not cause as many problems as intestate succession. For one thing, bequest between Muslims and non-Muslims is permitted. But the rule that not more than one third can be bequeathed is considered to be of public policy only when either the testator or the beneficiaries are Muslim. NonMuslims may bequeath more than one third of their property, provided the beneficiaries are also non-Muslims. ${ }^{109}$

\subsection{Changing religion}

In matters of personal status, religion is not a private matter anymore, but determines one's legal status. A non-religious person or a person not adhering to one of the recognized monotheistic religions will be judged according to Islamic law. The effect of religion becomes all the more clear in case of conversion. Regardless of a person's personal convictions for converting to another religion, from a legal perspective it means that he has passed into the realm of another personal status law. Conversion might therefore even become a convenient tool to achieve certain legal goals. By converting to Islam, for instance, the wife renders the marriage with her non-Muslim husband void, which is a much easier way of divorce than those offered by Christian laws. Conversion to Islam may also be a way to exclude the next of kin from the inheritance.

Changing from a non-Muslim religion to Islam

The scope of Islamic public policy rules is not limited to foreigners who are Muslim, but includes also foreigners who have recently converted, even when this conversion takes place during litigation. As a matter of public policy, conversion to Islam renders Islamic law immediately applicable, regardless of the nationality of the convert. ${ }^{110}$ For conversion to Islam, the only requirement is to pronounce the shahada or "testimony of faith" ("There is no god but God, and Muhammad is His messenger") in the presence of two witnesses. ${ }^{111}$ The argument that conversion in Lebanon is only valid when it is registered with the proper authorities was deemed irrele-

109. Ibrahim, supra n. 1, at 307; Khalid, supra n. 33, at 265ff.; Riyad, supra n. 16, at 291; Salama, supra n. 1, at 963; Sadiq, supra n. 23, at 329; Shawqi, supra n. 28, at 387. Court of Cassation, Majmu'at al-Ahkam li-Mahkamat al-Naqd, No. 8, Year 35, 26 July 1967; No. 59, Year 39, 12 February 1975; No. 7, Year 42, 19 January 1977.

110. Confirmed by the Court of Cassation in Majmu'at al-Ahkam li-Mahkamat alNaqd, No. 31, Year 15, 10 January 1946.

111. Court of Cassation, Majmu'at al-Ahkam li-Mahkamat al-Naqd, No. 27, Year 40, 11 December 1974; No. 8, Year 44, 21 January 1976; No. 27, Year 45, 1 March 
vant by the Court of Cassation: conversion to Islam, it argued, can as a rule of public policy not be any different than what Islamic law requires. ${ }^{112}$

The immediate applicability of Islamic law is based on the principle that a non-Muslim law should be denied authority over a Muslim, as neatly summarized in the Islamic maxim that "Islam supersedes and cannot be superseded."113 It is said that the convert enjoys all the rights of a Muslim in the field of personal status law. ${ }^{114}$ However, as mentioned before, conversion to Islam by a foreigner does not mean that Islamic law is applied in its entirety, but the convert is only granted those rights of Islamic law which public policy deems inalienable. The example most commonly used in the legal literature is the right of unilateral divorce (talaq). Both the Egyptian legal literature and the court law are unanimous in their opinion that conversion to Islam by a foreign husband entitles him to the use of talaq by virtue public policy. ${ }^{115}$ For the same reason, the foreign woman who has converted to Islam will be granted judicial divorce (tatliq) if her husband is not Muslim, based on the rule that a Muslim woman may not be married to a non-Muslim man. ${ }^{116}$ Other examples from case law are the husband of a Christian British couple who converted to Islam and was consequently obliged under Islamic law to pay his wife maintenance (nafaqa), but was released from the obligation under his national law to pay her alimony after he had divorced her because that obligation is not known in Islamic law. ${ }^{117}$ Also, based

1978; No. 34, Year 55, 27 November 1990; No. 152, Year 59, 24 June 1992; No. 36, Year 61, 25 December 1995.

112. Court of Cassation, Majmu'at al-Ahkam li-Mahkamat al-Naqd, No. 28, Year 45, 1 March 1978; No. 10, Year 48, 20 June 1979.

113. 'Abd al-Wahab, supra n. 47, at 201.

114. See, e.g., Cairo Court of First Instance, 12 June 1952 and 16 December 1952 (quoted by Linant de Bellefonds, supra n. 4, at 843).

115. Court of Cassation, Majmu'at al-Ahkam li-Mahkamat al-Naqd, No. 31, Year 15, 10 January 1946, and No. 29, Year 30,30 January 1963. The right of divorce as a consequence of conversion was also granted by lower courts: Cairo Court of Appeal, 12 June 1952, 6 Muhamah 900 (1952), and Cairo Court of First Instance, No. 2666, Year 1949, 12 June 1951 ('Abd Allah, supra n. 10, at 304); No. 26, Year 1959, 16 December 1952 ('Abd Allah, supra n. 10, at 253); 22 February 1955 ('Abd al-Wahab, supra n. 47, at 199). See for legal literature: 'Abd Allah, supra n. 10, at 304; 'Arafa, supra n. 31, at 294; Khalid, supra n. 33, at 227; Rifa'i, supra 47, at 14; Riyad, supra n. 16, at, 237; Sadiq, supra n. 23, at 298; Salama, supra n. 1, at 856; Shawqi, supra n. 28, at 131 .

116. Court of Cassation, Majmu'at al-Ahkam li-Mahkamat al-Naqd, No. 76, Year 53, 27 January 1987. Divorce for the same reason was pronounced in rulings by lower courts which are all unpublished but quoted from legal literature: Cairo Court of Appeal, 13 February 1951 and 18 December 1951 (Khalid, supra n. 33 at 228) and Cairo Court of First Instance, No. 13, Year 1950, 13 February 1951; No. 140, Year 1950, 18 December 1951; No. 143, Year 1952, 27 October 1952 ('Abd Allah, supra n. 10 , at 304).

117. Court of Cassation, Majmu'at al-Ahkam li-Mahkamat al-Naqd, No. 31, Year 15, 10 January 1946. In similar cases of Egyptian husbands who converted to Islam and pronounced a talaq in order to avoid an earlier issued Christian court order to 
on the public policy nature of both polygamy and conversion to Islam, it must be assumed that the foreign, non-Muslim man is upon conversion entitled to enter into a second, polygamous marriage. ${ }^{118}$

Changing from Islam to a non-Muslim religion

As in Islamic law, apostasy from Islam is not allowed in Egypt even though this rule is not codified in Egyptian legislation. While apostasy from Islam is a capital offense in the Islamic figh-literature, it is not prohibited in Egypt in the sense that it is punishable. However, apostasy from Islam has serious repercussions in the field of personal status law: it renders the marriage of the apostate null and void, prevents him from entering into a (new) marriage - even with a non-Muslim - and excludes him from inheritance.

In apostasy cases relating to Egyptians, the Court of Cassation considered in a ruling as far back as 1966 that the prohibition of apostasy from Islam is a rule of the general law, ${ }^{119}$ but ruled in 1975 that it pertains to public policy, ${ }^{120}$ and in 1996 argued that it is based on 2 of the Constitution which stipulates that Islam is the state religion and Islamic law the main source of legislation. ${ }^{121}$ However, neither the Court nor the legal literature give any indication as to whether the prohibition of apostasy from Islam also has repercussions for Muslim foreigners who have apostatized and appear before an Egyptian court. This must be assumed to be the case, however, given the importance of this rule in Islamic law and the scope of public policy as observed so far. ${ }^{122}$

\section{Changing from one non-Muslim sect or rite to another}

As a matter of internal conflicts law, a difference in religion between non-Muslims spouses renders Islamic law applicable to their marriage and divorce. Here also, converting to another non-Muslim religion or sect can make all the difference with regard to applicable personal status law. One of the partners of a Coptic-Orthodox couple may consider becoming a Greek-Orthodox so that Islamic law may

pay alimentation after divorce, the Court introduced a grace period of one year in which the alimentation remained due (No. 4, Year 25, 25 February 1956 and No. 532, Year 26, 30 January 1963).

118. 'Abd al-Wahab, supra n. 47, at 203.

119. Court of Cassation, Majmu'at al-Ahkam li-Mahkamat al-Naqd, No. 20, Year 34, 30 March 1966.

120. Court of Cassation, Majmu'at al-Ahkam li-Mahkamat al-Naqd, No. 9, Year 44, 14 December 1975.

121. Court of Cassation, Majmu'at al-Ahkam li-Mahkamat al-Naqd, Nos. 475, 478, 481, Year 65, 5 August 1996.

122. Indicative in this respect might be the observation that a foreign law which does not allow a Muslim woman to divorce from her husband who apostatized from Islam, will be considered in violation of Egyptian public policy (Ibrahim, supra n. 1, at 258). 
make divorce easier. On the other hand, a Maronite husband of a Coptic woman may want to convert to his wife's religion in order to avoid Islamic law to be applicable. All these issues are related to internal conflicts law and are of no relevance for the issue of public policy, because this conversion is unrelated to Islam. Within the context of (internal) conflicts law, however, it is definitely relevant for the foreigner married to an Egyptian, because, as explained before, the religion of the foreigner is taken into account when determining the applicable Egyptian personal status code.

\section{Comparative Analysis of Egyptian Public Policy}

It has become apparent from the previous paragraphs that in matters of personal status, Egyptian conflicts law has two distinctive policies: one for Muslim foreigners and one for all foreigners (both Muslim and non-Muslim), which I suggested to name "Islamic" and "general" public policy, respectively. Non-Muslim foreigners are allowed to apply their own rules even when these are a blatant violation of the essential values and principles of Islamic law. A kind of reciprocal tolerance seems to be the underlying assumption: we Muslims claim our rights for our people as you non-Muslims may claim yours for your people. This looks very much like a mitigated application of Islamic conflicts law. Mitigated, because Islamic law is not entirely applied to Muslim foreigners as used to be the case until the late $19^{\text {th }}$ century, but only the rules of Islamic law which are deemed of essential importance. Public policy is the tool which determines these rules. In the following, the functions of Islamic and general public policy will be further examined.

Interesting in this respect is that a third public policy is lacking, namely that of non-Muslim religious principles. The domestic religious principles of the non-Muslims are not elevated to the level of public policy. Egyptian public policy is only concerned with Muslims. A Catholic foreigner will have his national law applied, irrespective of any violation of essential principles of Islamic or Catholic law. ${ }^{123}$

\subsection{Functions of general public policy}

The Egyptian public policy that applies to all foreigners, regardless of their religion, is the public policy familiar to most civil law doctrines. It has a defensive ("negative") function, meaning that if Egyptian conflicts rules have designated foreign law to be the appli-

123. When comparing the inventory of public policy rules relating to non-Muslim foreigners with that relating to non-Muslim Egyptians (see Berger, supra n. 17), the tentative conclusion may be drawn that public policy interferes in non-Muslim Egyptian matters more than in those of non-Muslim foreigners. This apparent distinction of public policy between internal and international matters will be the subject of an upcoming article. 
cable law, this application might be forestalled if the result is harmful or disruptive to the national legal order. The survey of the previous paragraph has yielded only three rules of Islamic law which may - I emphasize the supposition - be considered of "general" public policy, although Egyptian legal doctrine is not unanimous regarding their public policy character: the relatives with whom marriage is not allowed (maharim); the marital obligations of obedience ( $t a^{\prime} a$ ) by the wife and maintenance (nafaqa) by the husband; the interdiction to acknowledge illegitimate children.

In addition to these rules, reference should also be made to the casual mention in the legal literature of rules which constitute "general principles of freedom and equality as adhered to in Egyptian society"124 and as such constitute a violation of "general" public policy. The examples usually mentioned are discriminatory rules based on color or ethnicity. ${ }^{125}$ Occasional reference is made to discrimination based on gender or religion, although the interpretation of what discrimination means in these two cases is quite different from most Western concepts. ${ }^{126}$ There is no case law on these issues, and it should be assumed that they serve merely as textbook examples of public policy, just like - or maybe even copied directly from - the European legal literature.

\subsection{Functions of Islamic public policy}

Islamic public policy does not represent a set of fundamental principles on which the legal order is based, but rather a number of

124. Ibrahim, supra n. 1, at 221,228 . Salama (supra n. 1, at 781) says that these are either related to "the principle of freedom of marriage" or to "the principle of equality between man and woman."

125. 'Arafa, supra n. 31, at 272, 327; 'Abd Allah, supra n. 1, at 189; 'Abd alRahman, supra n. 1, at 299; Fahmi, supra n. 28, at 515-16; Ibrahim, supra n. 1 , at 221; Khalid, supra n. 33, at 254; Riyad, supra n. 16, at 158; Sadiq, supra n. 23, at 278; Salama, supra n. 1, at 781, 947; Shawqi, supra n. 28, at 257.

126. 'Abd Allah, supra n. 10, at 339; Ibrahim, supra n. 1, at 289; Khalid, supra n. 33, at 254; Riyad, supra n. 16, at 280; Sadiq, supra n. 23, at 204; Salama, supra n. 1, at 608,947 ; Sayyid, supra n. 29 , at 399 ; Shawqi, supra n. 28, at 156.

The prohibition of discrimination based on gender only applies when the woman is excluded from certain rights. The example commonly used is the exclusion of the woman from inheritance. The fact that there is a difference between the rights of a man and a woman is not considered condemnable. On the contrary, differences between men and women in matters of personal status are endorsed by Islamic law (and most non-Muslim laws in Egypt, for that matter). For example, in matters of inheritance the foreign rule which excludes the daughter as heir in favour of the son is considered a violation of public policy, while the Islamic fule that a woman's share is half of the man's share is itself a rule of public policy.

Discrimination based on religion is obviously not a matter of concern, since the very structure of personal status law in Egypt is based on this distinction. This does not mean that all discriminatory rules based on religion will pass the litmus test of Egyptian public policy. If these rules violate the rights of Muslims (such as prohibiting a Muslim man to marry a non-Muslim woman) it will be considered an infringement of public policy. 
specific rules. It appears that the common denominator of these rules is their mention in the Quran, which renders them directives ordained by God Himself and hence essential rules of Islamic law. The survey of the previous paragraph has yielded the following public policy rules (the rules which are mentioned only by one or two authors, or which are disputed otherwise, are put between brackets):

- The prohibition of a marriage between a Muslim woman with a non-Muslim man (and its mirror image rule: allowing for a marriage between a Muslim man and a non-Muslim woman);

- The husband's right of polygamy;

- Marriage conditions: a) mutual consent (taradi) between bride and groom and $b$ ) the presence of two male Muslim witnesses (ishhad);

- The relatives with whom marriage is not allowed (maharim);

- [Prohibition of re-marriage without observing the waiting period ('idda) after divorce or decease of the husband]

- [The bridal gift (mahr)]

- [The prohibition of adoption]

- The interdiction to acknowledge illegitimate children;

- Unilateral divorce (talaq) by the husband;

- Certain rules of Islamic intestate law, the most important being: a) the share of the woman is half of her brother's, b) the order of precedence of the relatives assigned as heirs by the Quran, c) the size of each of the shares allotted by the Quran;

- Intestate succession between a Muslim and non-Muslim;

- Bequest of the testator amounting to more than one third of his property;

- Conversion to Islam renders Islamic law immediately applicable;

- Conversion to Islam becomes effective as of the pronouncement of the shahada;

- [The prohibition of apostasy from Islam.]

These are what I have called the "rules of Islamic public policy."127 It would be tempting to add all remaining legal injunctions mentioned in the Quran, and complete the corpus of rules on which Islamic public policy is based. The fact that this has not already been done in the legal literature calls for caution. On the other hand, the legal literature generally asserts that it merely provides examples,

127. It should be remarked that they are usually referred to as "rights," which seems a wrong use of the term but should be understood in the context of Islamic law. Islamic legal literature calls "the rights of God" those rights as well as obligations, prohibitions and impediments which $\mathrm{He}$ has specifically granted to man (most often by means of mention in His Word, the Quran). They are inalienable in the strictest sense of the word: they can not be waived or denied, and the self-evidence with which they are mentioned in the legal literature - i.e., without any justification or foundation - suggests a deep-rooted conviction of their universal (for Muslims, that is) status. 
implying that the list could be longer. Of interest, for example, would be the case of custody regarding foreign Muslim children. Will a foreign judgement which awards the custody of young minors to the father, or that of older minors to the mother, be considered a violation of Islamic public policy now that Islamic law has set principal rules to the opposite: mothers have by law the exclusive custody over younger minor children, and fathers the exclusive custody over older minors.

\subsection{Defining Islamic public policy - a comparative approach}

In the previous paragraphs we have seen that the public policy mentioned in the Egyptian Civil Code is derived from, and inspired by the - mainly French - legal doctrine of civil law, and is defined accordingly by the Egyptian legal literature, but in practice operates quite differently when it comes to matters of personal status. In this paragraph I want to further examine these differences in order to see whether Egyptian public policy indeed lives a life of its own or is in some way still connected to its European origin.

Let us take the example of polygamy and assume the case of an English couple in Egypt, the husband having married a second wife. For the sake of argument we will use two scenarios: one is that the Englishman marries his second (English) wife in Egypt, the other that he has married his second (Greek) wife in Greece. What will the Egyptian court do when his first - English - wife requests the nullity or non-recognition, respectively, of the second marriage (for example because the man has deceased and she claims to be the sole heir)? In the first scenario the case is one of conflicts rules: the validity of the second marriage is based on the national law of both parties involved (Article 12 Civil Code) and English law declares a bigamous marriage null and void. In the second scenario the case is one of recognition of a foreign legal act. The court's decision in both cases depends on the religion of the husband: if he is a Muslim, the court will declare the marriage valid in the first case and recognize it in the second, both as a matter of public policy. If, on the other hand, the husband is not a Muslim, his second marriage will not be deemed valid and not recognized by virtue of English and Greek law, respectively.

The question is, what kind of public policy are we dealing with? The Egyptian legal literature spends many pages explaining public policy and its meanings, applications and functions, but it fails to do so in relation to matters of personal status. The Egyptian legal literature is unanimous in referring to the mechanism of public policy as an 'exception' or 'safety valve.' This implies that public policy plays the part of a corrective device which only comes in to action at the end of the process of conflicts rules. As such it constitutes public pol- 
icy in its negative function. Accordingly, the Egyptian court should proceed as follows: a) based on the conflicts rules, which refer to the nationality of the parties, the applicable law is established; b) when the applicable law is a foreign law, it is put to the test of Egyptian public policy, and c) when the foreigner is a Muslim, the foreign rules violating public policy are substituted by the relevant essential rules of Islamic law. This is the picture portrayed by the legal literature. I am of the opinion, however, that this process of applying Egyptian conflicts law does not correspond to its practice in the Egyptian courts.

In practice the court applies a two-track approach, based on a second connecting factor: religion. When the Englishman in our example is Muslim, the court will continue on the track of Islamic public policy rules. When he is not Muslim, the court will continue on the tract of conflicts rules, and apply the law of nationality, as determined by these conflicts rules. It is only in the second track that public policy operates negatively, but only in its function of what I have called 'general' public policy. When the parties are Muslim, however, a whole set of rules (i.e. those considered essential to Islamic law) becomes automatically applicable. This portrays public policy more in its positive function, since these rules of Islamic law will be applied, not as an exception, but as a prerogative of the forum. The prerequisites of negative public policy - the court's scrutiny of the reasons for the prohibition of bigamy in English and Greek law, and its examination of any possible harm the application of these laws will do to Egyptian society ${ }^{128}$ - become obsolete the moment the Englishman's Islamic religion has been established. Islamic public policy is therefore reminiscent of Mancini's (positive) public policy: it constitutes a set of rules, the obligatory application of which precedes the conflicts rules rather than being the exception to it at the end of the procedure.

A few Egyptian scholars have presented an alternative view by defining negative public policy as denying a foreigner his rights acquired under his national law, and positive public policy as granting a foreigner a right which might be denied to him under his national law. ${ }^{129}$ This view is unsatisfactory, however, since Islamic public policy rules are applied directly - I would even say: blindly - without regard for the difference between acquired and denied rights under foreign law, nor, for that matter, for the difference between, on the one hand, recognition of foreign legal acts and awards and, on the other hand, application of foreign law. This absolute character of Is-

128. Cf. Paul Lagarde, "Public policy," in International Encyclopedia of Comparative Law, Vol. 3 (Private International Law) 8ff. (Lipstein, 1994).

129. 'Abd Allah, supra n. 11, at 535-36; Fahmi, supra n. 29, at 515-16; Sadiq, supra n. 23 at $209,212$. 
lamic public policy also shows in the lack of consideration for the existence - or absence - of a link between the foreign issue and the Egyptian forum. Where European courts may as a matter of "reduced" public policy recognize a polygamous marriage which has been validly concluded abroad, while refusing to allow its legal effects to materialize in their respective countries, Egyptian courts will not make such differentiations. The court in our example will apply the Islamic public policy rule regardless of the legal status of the second marriage in Greece, and irrespective whether the parties are residing in Egypt or are merely tourists passing through. The court would rule with the same 'blindness' in the case when not the Englishman but his first wife were Muslim: this marriage would be deemed invalid, whether as a matter of non-recognition or of non-applying foreign law, and without consideration for the validity of the marriage in the country where it was concluded.

As mentioned before, the strong positive nature of Islamic public policy, its appearance as a set of rules and its operation as an autonomous connecting factor is reminiscent of the Mancini's doctrine. The crucial difference between the Islamic concept of public policy and Mancini's concept, however, is the nature of the connecting factor. Where Mancini advocated nationality as a connecting factor, with its strong territorial bonds, Islamic public policy, on the other hand, uses religion as a connecting factor which by its nature has no territorial affiliations. This leads to perhaps the most important characteristic of Islamic public policy: its universality, albeit limited to Muslims. It does not seek to protect those Islamic values which are an essential part of the Egyptian society, but rather the (essential) Islamic "rights" of the Muslims all over the world. In other words, Islamic public policy does not guard national interests confined to a national territory, but inalienable interests related to an international religious community. Applying the Islamic public policy rules is considered to be in the interest, in fact a right, of every Muslim.

This evokes a strong parallel with the concept of fundamental rights in Western legal context. These rights are also considered inalienable and universal, attributes of people because of their humanity and hence disregarding any national or territorial links. The intervention of fundamental rights in conflicts law, however, is still a matter of debate in Western legal doctrine. In France, for instance, there is a reluctance to apply fundamental rights within the framework of conflicts law, mainly because of legal technicalities related to the use of public policy. ${ }^{130}$ Germany, on the other hand, has gone so far as to change its Civil Code in 1986, Article 6 now stipulating that applica-

130. See, e.g., Hamje, "Droits fondamentaux et ordre public," 1 Revue Critique de Droit International Privé (1997) and Batiffol and Lagarde, Traité de Droit International Privé No. 365 (1993). 
ble foreign laws may not violate the 'fundamental principles (Grundsätzen of German law' as well as 'fundamental rights ('Grundrechten'). This does not mean, however, that the fundamental rights can be applied directly, as a public policy in its positive sense. On the contrary, the same conditions as for public policy must be fulfilled, i.e. the foreign law needs to be scrutinized, the circumstances of the case are to be taken into account as well as the proximity between case and forum (the so-called Inlandsbeziehung). ${ }^{131}$

This brings us to the conclusion that, while Islamic public policy may be compared to the Western fundamental rights in terms of nature and characteristics, the latter does not have the force of direct and 'blind' intervention as Islamic public policy has. In the latter case, the rules are considered to be relevant in themselves, devoid of any need for adaptation to circumstances or people, which is logical if one considers that these rules are "rights of God," meaning that they have no relation to any country or international treaty. These rules are not flexible (although any Egyptian textbook on public policy will emphasize that they are), but by their very nature unchangeable. God's rights granted to mankind are not to change with time and place, but to remain eternally as a divine right. ${ }^{132}$ To give this public policy the attributive "Islamic" is therefore justified in more than one respect.

\subsection{The silence surrounding Islamic public policy}

The most puzzling aspect of Islamic public policy, I find, is that it is completely ignored by both the Egyptian conflicts law and legal literature. The dichotomy between "Islamic" and "general" public policy is never a matter of discussion, even though these two concepts are entirely different in scope, nature and procedure. ${ }^{133}$ The Egyptian legal literature's approach to Islamic public policy is enigmatic, to say the least. For instance, while the connecting factors like nationality or domicile receive abundant attention, (Islamic) religion as connecting factor is never mentioned. The changing nature of public policy is always emphasized, but no reference is made to the inflexibility of Islamic public policy. Also, when the history of conflict rules and public policy is told, it is always the European history, and hardly ever that of Islamic law. Although there is unanimity when it comes to the application of Islamic public policy rules, the fact that

131. Jayme, Methoden zur Konkretisierung des Ordre public im Internationalen Privatrecht 14-15 (1989); Kegel, Internationales Privatrecht 381-83 (1995); Lagarde, supra n. 128, at 54-56; Spickhoff, Der ordre public im intrnationalen Privatrecht: Entwicklung, Structur, Konkretuserung 123-27 (1989).

132. This inflexibility of Islamic public policy is only occasionally mentioned in the Egyptian legal literature on internal conflicts law (see for references: Berger, supra n. 17).

133. An exception is Riad and Sadek, supra n. 47 , at 74 . 
these create a conflicts law which is distinctly different from that codified by Egyptian law is no reason for elaboration or explanation, let alone for recognition of a separate system of conflicts law when it comes to personal status. One is led to believe from the casual way the rules of Islamic public policy are mentioned that they are so selfevident that one does not need to waste many words on it. This is not in line, however, with the thorough and verbose tradition of legal scholarship.

What explains this attitude? It is not a matter of discomfort with regard to Islamic law, because it is obvious from the literature that the Egyptian scholars are very proud of that legal heritage. Most probably the cause lies within the Egyptian legal tradition of private international law itself. This scholarship has in the past century been entirely based on European law. As has been observed, the Islamic system of conflicts law is quite alien to the European system. It appears that Egypt's dogmatic legal tradition lacks the leverage to incorporate Islamic conflicts law into the existing European-based legal doctrine, and attribute it the position which it already has in practice.

A similar pressing question is why the legislature which is usually so meticulous in its work has so far not bothered to undertake any action. In the field of personal status, Islamic public policy has such far-reaching consequences that one may wonder whether it is justified to leave it buried away under the (European) civil law notion of public policy. This holds also for the case of religion as connecting factor. It would be much more clear and straight forward if an additional conflicts rule was inserted in the Civil Code stipulating that essential rules Islamic law would apply to any Muslim, regardless of his or her nationality. The legislature nor the legal literature has ever considered this option. An exception is mentioned by Riad and Sadek when they quote with approval an anonymous author who has written: "Why would we preserve the Egyptian system of conflicts law? Wouldn't it be better to replace it with a single and more simple rule which stipulates that the Muslim foreigner is subjected to Islamic law and the non-Muslim foreigner to his national law?"134 $\mathrm{Al}$ though this is a bit exaggerated - we have seen that only some, essential, rules of Islamic law apply to the Muslim foreigner - it reflects the awkwardness of Egyptian conflicts law in matters of personal status.

\section{ConClusion}

With regard to matters of personal status, Egyptian conflicts rules use two connecting factors: nationality and religion. Nationality is a connecting factor typical of European conflicts law which has

134. Riad and Sadek, supra n. 47 , at 84 . 
been incorporated in the Egyptian Civil Code. Religion as connecting factor originates from Islamic conflicts law which from a point of view of legal doctrine is not part of contemporary Egyptian conflicts law, but is nevertheless introduced by virtue of the public policy exception of Article 28 of the Civil Code.

Public policy in Egyptian conflicts rules regarding personal status consists of two kinds: a "general" and an "Islamic" public policy. The general policy is very much like its European origin. The Islamic public policy, however, is distinctively different. First, it does not aim at protecting national interests or values, but at the rights of the global community of Muslims. When a foreign Muslim is denied by his national law the rights which he would enjoy under Islamic law, this will be considered a violation of Egyptian public policy and the foreign law will be substituted by Islamic law.

Second, the rules which Islamic public policy aims to safeguard are not Islamic law in its entirety but only its essential rules. A survey of the cases where Islamic public policy was applicable shows that the rules involved were mostly directly based on the Quran. These God-given rules are by their very nature considered to be immutable. This is in contrast with the European concept of public policy, which is considered to be changing with time and place, in accordance with the needs of society.

Non-Muslim foreigners are hardly touched by this public policy, meaning that rules of foreign laws which are contradictory to Islamic law will nevertheless be applied if the foreigner involved is not Muslim. This separation of legal spheres is a typical feature of Islamic conflicts law: Islamic personal status law will be applied to those who are under the religious (rather than territorial) jurisdiction of Islam, i.e. the Muslims, regardless of their nationality or place of residence.

Considering these characteristics it may be concluded that Islamic public policy has a strong positive character, comparable to the public policy as advocated by Mancini. As such it is a misleading term because it has nothing to do with public policy as generally adhered to by Egyptian legal doctrine. Islamic public policy is not so much the often quoted "safety valve" which prevents unwanted consequences from foreign laws to affect the national order, but rather a valve through which Islamic conflicts law is introduced.

Finally, the negligence of the otherwise meticulous and conscientious Egyptian legal doctrine in this matter is conspicuous. That religion is a more important connecting factor than nationality in matters of personal status is not mentioned by the law or the legal literature. This puzzling and sometimes even spurious attitude towards Islamic public policy might be explained with the considera- 
tion that Islamic conflicts law as practiced by the courts does not fit into the European legal doctrine practiced by the legal scholars. 